\title{
Transgenic Expression of Tobacco mosaic virus Capsid and Movement Proteins Modulate Plant Basal Defense and Biotic Stress Responses in Nicotiana tabacum
}

\author{
G. Conti, ${ }^{1,2}$ M. C. Rodriguez, ${ }^{1,2}$ C. A. Manacorda, ${ }^{1}$ and S. Asurmendi ${ }^{1,2}$ \\ ${ }^{1}$ Instituto de Biotecnología, CICVyA-INTA, Hurlingham, Buenos Aires, Argentina; ${ }^{2}$ Consejo Nacional de Investigaciones \\ Científicas y Técnicas (CONICET), Buenos Aires, Argentina
}

Submitted 31 March 2012. Accepted 14 June 2012.

\begin{abstract}
Plant viruses cause metabolic and physiological changes associated with symptomatic disease phenotypes. Symptoms involve direct and indirect effects, which result in disruption of host physiology. We used transgenic tobacco expressing a variant of Tobacco mosaic virus (TMV) coat protein $\left(\mathbf{C P}^{\mathrm{T} 42 \mathrm{~W}}\right)$ or movement protein (MP), and a hybrid line $\left(\mathrm{MP} \times \mathrm{CP}^{\mathrm{T} 42 \mathrm{~W}}\right)$ that coexpresses both proteins, to study the plant response to individual viral proteins. Findings employing microarray analysis of $\mathrm{MP} \times \mathrm{CP}^{\mathrm{T} 42 \mathrm{~W}}$ plants and silenced $\mathrm{mp} \times \mathrm{cp}^{\mathrm{T} 42 \mathrm{~W}}$ controls revealed that altered transcripts were mostly downregulated, suggesting a persistent shut-off due to $\mathrm{MP} \times \mathrm{CP}^{\mathrm{T} 42 \mathrm{~W}}$ expression. Next, we showed that MP triggered reactive oxygen species (ROS) accumulation, reduction of total ascorbate, and expression of ROS scavenging genes. These effects were enhanced when both proteins were coexpressed. MP and MP $\times C^{\mathrm{T}} \mathrm{P}^{\mathrm{T} 2 \mathrm{~W}}$ plants showed increased levels of salicylic acid (SA) and SA-responsive gene expression. Furthermore, these effects were partially reproduced in Nicotiana benthamiana when GMP1 transcript was silenced. $\mathrm{CP}^{\mathrm{T} 42 \mathrm{~W}}$ seems to be playing a negative role in the defense response by reducing the expression of PR-1 and RDR-1. MP and $\mathrm{MP} \times \mathrm{CP}^{\mathrm{T} 42 \mathrm{~W}}$ transgenic expression promoted a recoverylike phenotype in TMV RNA infections and enhanced susceptibility to Pseudomonas syringae and Sclerotinia sclerotiorum. The individual effects of viral proteins may reflect the ability of a virus to balance its own virulence.
\end{abstract}

Viral diseases cause a great diversity of symptoms, producing irreversible yield losses in cultivated plants. Plant viruses often induce a number of common metabolic and physiological alterations that are probably the cause of the symptomatic phenotypes of disease. Virus-susceptible host interactions results in interference or competition for host resources and involve direct effects, which contribute to the establishment of a systemic infection, and side effects, which do not contribute to the success of the infection but indirectly disrupt host physiology. Plant gene expression is altered during virus infection and it has been reported that, like animal viruses, plant viruses are capable of reprogramming and disrupting host gene expression in a phenomenon known as "shut off" (Aranda and Maule 1998; Havelda et al. 2008). Genes involved in many cel-

Corresponding author: S. Asurmendi;

E-mail: sasurmendi@cnia.inta.gov.ar

* The $\boldsymbol{e}$-Xtra logo stands for "electronic extra" and indicates that three supplementary figures and two supplementary tables are published online. Also, Figures 1, 2, 4, 5, and 6 appear in color online. lular processes such as phytohormone signaling, cell cycle control, and endogenous transport of macromolecules and cellwall- and plastid-related genes, among others, are either induced or repressed upon infection (Bazzini et al. 2011; Pallas and Garcia 2011; Shimizu et al. 2007; Whitham et al. 2006). Some of the distinctive gene expression changes resemble those observed in cellular stress and developmental defects (Whitham et al. 2006). The stress-like responses are characterized by the induction of heat-shock proteins (Aranda et al. 1996; Jockusch et al. 2001; Mayer 2005) and changes in the expression of several genes involved in reactive oxygen species (ROS) detoxifying mechanisms such as catalases, superoxide dismutases, peroxidases, and other redox-related genes (Li et al. 2005; Riedle-Bauer 2000).

The development of a systemic defense response triggered by a local ROS signal is mediated by salicylic acid (SA) production and by the induction of pathogenesis-related (PR) genes and other genes associated with plant disease defenses (Jones and Dangl 2006; Thimm et al. 2004; van Loon et al. 2006). The induction of many PR genes (Edreva 2005; van Loon et al. 2006; Yang et al. 1997) and other coregulated transcripts are involved in defense-like responses, which are usually mediated by defense hormones, predominantly SA (Loake and Grant 2007; Vlot et al. 2009). Although the induction of PR proteins is widely associated with disease defenses, none of them are known to have any antiviral effects (Cutt et al. 1989; Linthorst et al. 1989; Palukaitis et al. 2008).

Despite impressive advances in the study of plant resistance to pathogens, little is known about the plant response in a compatible virus interaction. In tobacco, Tobacco mosaic virus (TMV) replication is inhibited by SA treatment; which results in a reduced viral accumulation and a delayed appearance of disease symptoms (Naylor et al. 1998; Nie 2006). In compatible host-virus interactions, the expression of several defenserelated genes is induced by an SA-dependent signaling pathway (Huang et al. 2005; Whitham et al. 2003). Moreover, the treatment of tobacco with SA restricts TMV movement in epidermal tobacco cells (Murphy and Carr 2002). There is a limited understanding of the global response taking place in the reaction of compatible hosts to viral infections owing to its complexity. For instance, the reaction depends on various features such as the demands of the virus, host defenses, host stress factors, cellular responses, and local or systemic responses. Transgenic host plants expressing viral proteins can be used as a simplified experimental system that has the potential to discriminate the effects of individual gene products from the impact of virus replication (Maule et al. 2002). For example, the ectopic expression of the Cauliflower mosaic virus P6 gene in 
its host species, Arabidopsis, has been shown to elicit symptom-like effects such as late flowering and mild chlorosis (Cecchini et al. 1997; Zijlstra et al. 1996). In a similar approach, the expression of TMV 126-kDa protein fused to green fluorescent protein (GFP) in N. tabacum produces an increased susceptibility to some viruses (Harries et al. 2008).

Transgenic tobacco plants expressing TMV coat protein (CP) fail to develop symptoms and to accumulate virions when inoculated with TMV (Abel et al. 1986) owing to a phenomenon called CP-mediated resistance (CP-MR) (Beachy 1999). When the CP amino acid residue 42 (Thr) is mutated to Trp $\left(\mathrm{CP}^{\mathrm{T} 42 \mathrm{~W}}\right)$, there is an increase of CP $20 \mathrm{~S}$ aggregate amounts that could be responsible for the enhanced effect on the host and on the CP-MR level (Asurmendi et al. 2007; Bazzini et al. 2007; Bendahmane et al. 1997). In addition, $\mathrm{CP}^{\mathrm{T} 42 \mathrm{~W}}$ restricts cell-to-cell spread by reducing the production of movement protein (MP) during TMV replication (Bendahmane et al. 2002), and it induces mild heterologous resistance to other viruses (Bazzini et al. 2006). Thus, several mechanisms of action must be taking place during the $\mathrm{CP}-\mathrm{MR}$ phenomenon triggered by $\mathrm{CP}^{\mathrm{T} 42 \mathrm{~W}}$. Inoculation with TMV RNA partially overcomes protection against virus infection in $\mathrm{CP}$ transgenic plants (Nelson et al. 1987); in contrast, $\mathrm{CP}^{\mathrm{T} 42 \mathrm{~W}}$ transgenic lines still show some degree of resistance. Constitutive expression of MP in tobacco plants showed that this 30-kDa protein interacts with the plasmodesmata, modifies their exclusion limit, and facilitates cell-to-cell spread of the virus during infection (Atkins et al. 1991; Deom et al. 1987, 1990; Wolf et al. 1989). The TMV MP has been demonstrated to cause severe physiological alterations, such as carbohydrate partitioning and photosynthesis on host plants, when expressed under constitutive or tissue-specific promoters (Almon et al. 1997; Balachandran et al. 1997). Moreover, it is also very interesting to consider the outcome of the co-accumulation of CP and MP to achieve a better understanding of the infective process. For instance, in a previous study, the coexpression of $\mathrm{MP}$ and $\mathrm{CP}^{\mathrm{T} 42 \mathrm{~W}}$ on hybrid plants was accompanied by severe morphological changes, altered miRNAs accumulation, and poor fertility. In addition, it is worthy to note that no detectable silencing suppression activity in relation to defense signaling was detected on the mentioned proteins (Bazzini et al. 2007).

In this work, we applied a transgenic approach to study the disruption of the natural host physiology and the triggering of a defense response by individual TMV protein expression. We made use of transgenic Nicotiana tabacum lines expressing either a variant of TMV CP, a TMV MP, or both proteins. The coexpressing line was obtained by means of a genetic cross between the two single protein transgenic lines (this new line was called $\mathrm{MP} \times \mathrm{CP}^{\mathrm{T} 42 \mathrm{~W}}$ ). To study the differential expression patterns resulting from the transgenic coexpression of MP and $\mathrm{CP}^{\mathrm{T} 42 \mathrm{~W}}$ in a TMV natural host, we performed a microarray analysis. We further focused the analysis on several arraybased selected genes related to stress and defense pathways. Next, we evaluated the accumulation level of ROS and defense hormones, such as SA and jasmonic acid (JA). Finally, we evaluated the impact on the defense system of these transgenic plants when challenged against a wide spectrum of pathogens, and we also performed functional assays to examine the influence of an individual gene in the phenotype and defense response observed in $\mathrm{MP} \times \mathrm{CP}^{\mathrm{T} 42 \mathrm{~W}}$ plants.

\section{RESULTS}

The co-accumulation of TMV MP and $\mathrm{CP}^{\mathrm{T} 42 \mathrm{~W}}$ mediates global changes in gene expression.

To characterize the gene expression changes caused by the coexpression of TMV capsid proteins and MP in N. tabacum
'Xanthi', we monitored global gene expression patterns with a Tomato $10 \mathrm{~K}$ Affymetrix Microarray GeneChip comparing the isogenic transgenic lines $\mathrm{MP} \times \mathrm{CP}^{\mathrm{T} 42 \mathrm{~W}}$ (transgenic tobacco $\mathrm{SX}$ coexpressing MP and $\mathrm{CP}^{\mathrm{T} 42 \mathrm{~W}}$ genes) and $\mathrm{mp} \times \mathrm{cp}^{\mathrm{T} 42 \mathrm{~W}}$. The latter line was used as a control genotype, considering that local transgene insertions and genetic background are conserved between both lines but that the expression of the transgenes is silenced in $\mathrm{mp} \times \mathrm{cp}^{\mathrm{T} 42 \mathrm{~W}}$ (Bazzini et al. 2007). The array contains more than 10,000 Solanum lycopersicum probe sets to monitor gene expression of more than 9,200 S. lycopersicum genes. It has already been verified that this array is useful for several solanaceous species, including tobacco, owing to the high degree of sequence conservation between transcripts (Rensink et al. 2005). The gene expression matrix was analyzed in two concatenated phases. First, we considered transcripts of the genes relevant to treatment differentiation, defined by $P$ values $<$ 0.10 . In the second phase, we applied a $P$ value correction to control false discovery rates $($ FDR $)(P$ value $<0.05)$ to the set generated in the first instance, as previously reported by Benjamini and Hochberg (1995). Raw data of the experiment were deposited at Gene Expression Omnibus (GSE37905). The analysis yielded 28 genes showing statistically significant enhanced or reduced accumulation levels (Fig. 1A). The selected transcripts were categorized based on shared structural elements or inferred function making a comparison between tomato and tobacco genomes using BLAST (Table 1). The results comprised various subgroups, including genes related to oxidative stress and hormone response, signal transduction, transcriptional regulation, carbohydrate metabolism, and RNA
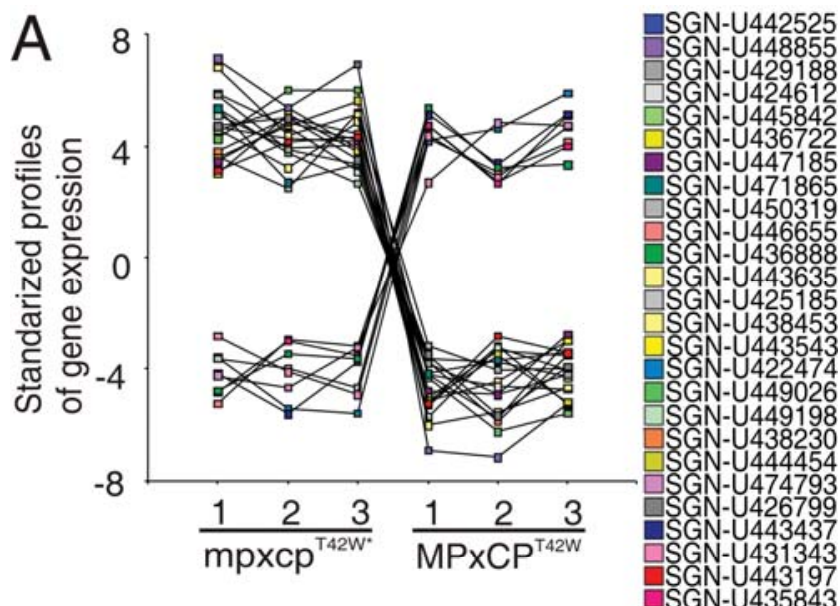

B

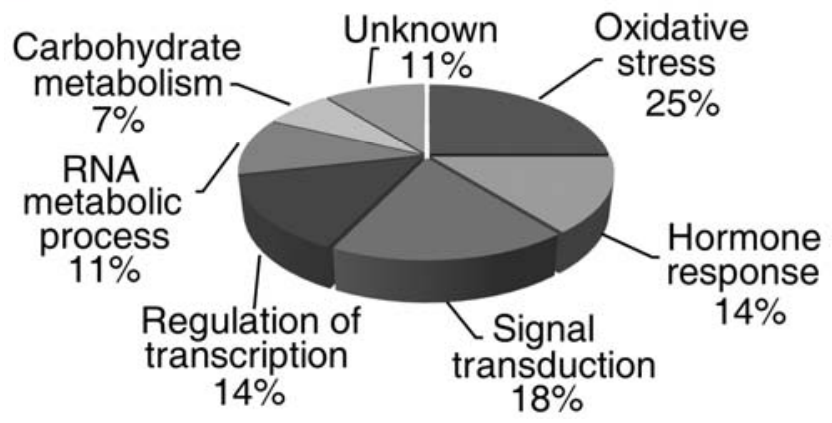

Fig. 1. Analysis of a tomato $10 \mathrm{~K}$ microarray. A, Standardized gene expression profiles along three biological replicates from a hybrid line coexpressing variants of Tobacco mosaic virus movement protein and coat protein $\left(\mathrm{MP} \times \mathrm{CP}^{\mathrm{T} 42 \mathrm{~W}}\right)$ and the silenced control $\left(\mathrm{mp} \times \mathrm{cp}^{\mathrm{T} 42 \mathrm{~W}^{*}}\right)$. B, Diagram representing the percentage of the putative biological functions of the genes differentially expressed. 
processing (Fig. 1B). These results were validated by reversetranscriptase quantitative polymerase chain reaction (RTqPCR) between the transgenic tobacco lines, confirming 16 of 23 genes tested (Supplementary Fig. S1); 5 genes were not tested because their PCR amplification failed using the available sequence data. Interestingly, most of the differentially expressed transcripts that were included in oxidative stress, hormone response, signal transduction, and metabolism functional categories were downregulated in plant lines coexpressing MP and $\mathrm{CP}^{\mathrm{T} 42 \mathrm{~W}}$ (Table 1). For the subsequent work, we focused on a group of genes related to oxidative stress and a second group associated with defense hormones. To deepen into the study of redox state and defense hormone regulation, we extended the analysis to a wider spectrum of genes and also to the parental transgenic $\mathrm{CP}^{\mathrm{T} 42 \mathrm{~W}}$ and MP lines and to wild-type SX tobacco plants.

\section{Viral proteins increase ROS accumulation and modulate ascorbic acid contents and redox scavenging gene expression.}

Considering that the $\mathrm{MP} \times \mathrm{CP}^{\mathrm{T} 42 \mathrm{~W}}$ line showed a reduced expression of genes involved in redox balance, we examined whether the transgenic expression of individual $\mathrm{CP}^{\mathrm{T}} 42 \mathrm{~W}$ and MP or the coexpression of both viral proteins altered the accumulation of ROS and ascorbic/dehydroascorbic acid levels (ASC/DHA) in leaf tissues. To achieve that aim, we performed histochemical staining to determine the accumulation of hydrogen peroxide $\left(\mathrm{H}_{2} \mathrm{O}_{2}\right)$ and superoxide ions $\left(\mathrm{O}_{2}^{-}\right)$using diaminobenzidine (DAB) and nitroblue tretrazolium (NBT), respectively. Results showed that $\mathrm{MP}$ and $\mathrm{MP} \times \mathrm{CP}^{\mathrm{T} 42 \mathrm{~W}}$ transgenic lines accumulated elevated levels of $\mathrm{H}_{2} \mathrm{O}_{2}$ and $\mathrm{O}_{2}^{-}$ compared with wild-type plants. These effects were more pronounced in the coexpressing line $\mathrm{MP} \times \mathrm{CP}^{\mathrm{T} 42 \mathrm{~W}}$, which also showed higher cell death (detected by trypan blue staining)
(Fig. 2A). Finally, the ASC/DHA measurements demonstrated that $\mathrm{MP} \times \mathrm{CP}^{\mathrm{T} 42 \mathrm{~W}}$ accumulated reduced levels of both antioxidant compounds (Fig. 2B). Altogether, these results suggest a synergic effect between these viral proteins enhancing an stress-like response phenotype in $\mathrm{MP} \times \mathrm{CP}^{\mathrm{T} 42 \mathrm{~W}}$ compared with MP plants. As expected, silenced $m p \times c p^{T 42 W^{*}}$ plants showed normal ROS and ASC/DHA levels, confirming that the effect is exclusively due to viral protein expression. On the other hand, $\mathrm{CP}^{\mathrm{T} 42 \mathrm{~W}}$ transgenic tobaccos behaved like wild-type controls, suggesting that $\mathrm{CP}$ alone fails to produce a stress-like phenotype similar to that observed with individual expression of MP or the combined expression of both transgenic proteins.

Based on the results of Figures 1 and $2 \mathrm{~A}$ and B, we also performed RT-qPCR in $\mathrm{CP}^{\mathrm{T} 42 \mathrm{~W}}$, MP, wild-type controls (SX), and systemic tissue of TMV-infected tobacco plants. The aim was to broaden the analysis made with $\mathrm{MP} \times \mathrm{CP}^{\mathrm{T} 42 \mathrm{~W}}$, to include a larger set of redox-related genes. The analysis of TMVinfected tobacco plants was performed early in infection (at 6 days postinfection [dpi], with no systemic viral accumulation) and in late infection (at $18 \mathrm{dpi}$, with high virus accumulation in systemic tissue) (Supplementary Fig. S2).

Results showed that GDP-mannose pyrophosphorylase 1 (GMP1) (SGN-U442525) transcript levels were reduced in $\mathrm{MP} \times \mathrm{CP}^{\mathrm{T} 42 \mathrm{~W}}$ and upregulated in TMV-infected plants at $18 \mathrm{dpi}$ (Fig. 2C). Detoxifying cytosolic ascorbate peroxidase (cAPX1) (SGN-U448855) did not change its expression level in any of the transgenic lines or TMV-infected plants at 6 dpi but it was upregulated in TMV-infected plants at 18 dpi (Fig. 2C). Chloroplast superoxide dismutase 2 (CSD2) (SGN-U313819) transcript levels were reduced in $\mathrm{MP} \times \mathrm{CP}^{\mathrm{T} 42 \mathrm{~W}}$ but it was upregulated in TMV infections at 18 dpi. Expression levels from all the transcripts measured were not altered in $\mathrm{CP}^{\mathrm{T} 42 \mathrm{~W}}$ and silenced $\mathrm{mp} \times \mathrm{cp}^{\mathrm{T} 42 \mathrm{~W}^{*}}$ (Fig. 2C). Finally, the relative level of detoxifying

Table 1. Differentially expressed tobacco unigenes (SGN) in plants overexpressing coat protein $(\mathrm{CP})^{\mathrm{T} 42 \mathrm{~W}}$ and movement protein (MP) versus silenced $\mathrm{mp} \times \mathrm{cp}^{\mathrm{T} 42 \mathrm{~W}^{*}}$ controls

\begin{tabular}{|c|c|c|c|}
\hline Tobacco unigene & Direction $^{a}$ & Description & Putative function \\
\hline SGN-U442525 & $\downarrow$ & GDP-mannose pyrophosphorylase (GMP1) & Oxidative stress \\
\hline SGN-U426799 & $\downarrow$ & GDP-D-mannose 4,6-dehydratase & $\ldots$ \\
\hline SGN-U424966 & $\downarrow$ & Plastid $\mathrm{Cu} / \mathrm{Zn}$ superoxide dismutase (CSD2) & $\ldots$ \\
\hline SGN-U44665 & $\downarrow$ & Similar to nucleobase-ascorbate transporter 6 (AtNAT6) & $\ldots$ \\
\hline SGN-U448855 & $\downarrow$ & Cytosolic ascorbate peroxidase (cAPX1) & $\ldots$ \\
\hline SGN-U429188 & $\downarrow$ & Ribophorin II (RPN2) & $\ldots$ \\
\hline SGN-U438230 & $\uparrow$ & Stress related protein & $\ldots$ \\
\hline SGN-U422474 & $\downarrow$ & Isochorismatase hydrolase family protein & Hormone response \\
\hline SGN-U424612 & $\downarrow$ & Nudix hydrolase similar to (AtNudH20) & $\ldots$ \\
\hline SGN-U450319 & $\downarrow$ & Ethylene-insensitive 4 (EIN4) & $\ldots$ \\
\hline SGN-U471865 & $\downarrow$ & Auxin-response putative protein & $\ldots$ \\
\hline SGN-U449198 & $\downarrow$ & Leucine-rich repeat transmembrane protein & Signal transduction \\
\hline SGN-U438453 & $\downarrow$ & Calcium dependent protein kinase (CPK4) & $\ldots$ \\
\hline SGN-U436722 & $\downarrow$ & Retromer-like protein complex (MAG1) (Ser-Thr Phosphatase) & $\ldots$ \\
\hline SGN-U447185 & $\downarrow$ & Endoplasmic reticulum (ER) lumen protein-retaining receptor protein & $\ldots$ \\
\hline SGN-U436888 & $\downarrow$ & ER putative signal peptidase & $\ldots$ \\
\hline SGN-U449026 & $\downarrow$ & Zinc finger (C3HC4-type RING finger) family protein & Transcriptional regulation \\
\hline SGN-U443635 & $\downarrow$ & Zinc finger protein $1(\mathrm{ZFN} 1)$ & $\ldots$ \\
\hline SGN-U435843 & $\uparrow$ & Similar to transducin family protein & $\ldots$ \\
\hline SGN-U474793 & $\uparrow$ & Similar to Nt-KED & $\ldots$ \\
\hline SGN-U426225 & $\uparrow$ & Putative DEAD/DEAH box helicase (RH16) & RNA metabolic process \\
\hline SGN-U443437 & $\uparrow$ & DEAD-box ATP-dependent RNA helicase (RH51) & $\ldots$ \\
\hline SGN-U431343 & $\uparrow$ & $3^{\prime}-5^{\prime}$-Exoribonuclease similar to exosome RRP42 & $\ldots$ \\
\hline SGN-U445842 & $\downarrow$ & Chlorophyll a/b binding protein 21 (LHCII type I CAB-21) & Metabolism \\
\hline SGN-U443543 & $\downarrow$ & Putative D-3-phosphoglycerate dehydrogenase & Unknown \\
\hline SGN-U444454 & $\downarrow$ & Unknown protein & $\ldots$ \\
\hline SGN-U425185 & $\downarrow$ & Similar to predicted protein Os08g0534400 & $\ldots$ \\
\hline SGN-U443197 & $\uparrow$ & Unknown protein & $\ldots$ \\
\hline
\end{tabular}

a Arrows $\downarrow$ and $\uparrow$ indicate downregulated or upregulated transcripts, respectively. 
alternative oxidase (AOX) (SGN-U450832) transcript was lower in $\mathrm{MP} \times \mathrm{CP}^{\mathrm{T} 42 \mathrm{~W}}$ and was not altered by TMV infection (Fig. 2C). The reduced levels of GMP1, CSD2, and AOX could play an important role in the enhanced stress-like phenotype observed in $\mathrm{MP} \times \mathrm{CP}^{\mathrm{T} 42 \mathrm{~W}}$.

In accordance with previously reported works (Fodor et al. 1997; Li et al. 2005; Wise et al. 2007), in this study, redoxrelated genes were induced at late stages of TMV infections (18 dpi) (Fig. 2C). However, even though an increment of detoxifying gene expression was expected, the sole MP expression produced no increase of the transcription levels of such genes, suggesting that this protein somehow deregulates the ROS scavenging system in host plants. Interestingly, the coexpression of $\mathrm{MP}$ and $\mathrm{CP}^{\mathrm{T} 42 \mathrm{~W}}$ showed a stronger phenotype associated with ROS increments, further reducing the detoxifying enzyme levels; which, in turn, enhanced this particular phenotype.

\section{MP expression increases SA levels and induces SA-responsive genes, whereas $\mathrm{CP}^{\mathrm{T} 42 \mathrm{~W}}$ expression produces a partial antagonistic effect.}

As stated in the differential transcript profiling of $\mathrm{MP} \times \mathrm{CP}^{\mathrm{T} 42 \mathrm{~W}}$ tobacco plants, the genes related to hormonal response (SA, ethylene, and auxins) exhibit altered expression patterns. It has already been reported that SA plays a crucial role in plant disease and pathogen resistance (Durrant and Dong 2004; Vlot et al. 2009). In particular, SA levels are increased in TMVresistant tobacco, which is paralleled with a raise in the expression of PR genes (Grant and Lamb 2006; Malamy et al. 1990; Vlot et al. 2009). For these reasons, in the following experiments, we focused on the study of SA levels and the expression of SA-responsive genes. First, we quantified SA and JA levels in the transgenic lines. Whereas SA was enhanced, JA was markedly reduced in leaves of MP and coex-

\section{A}
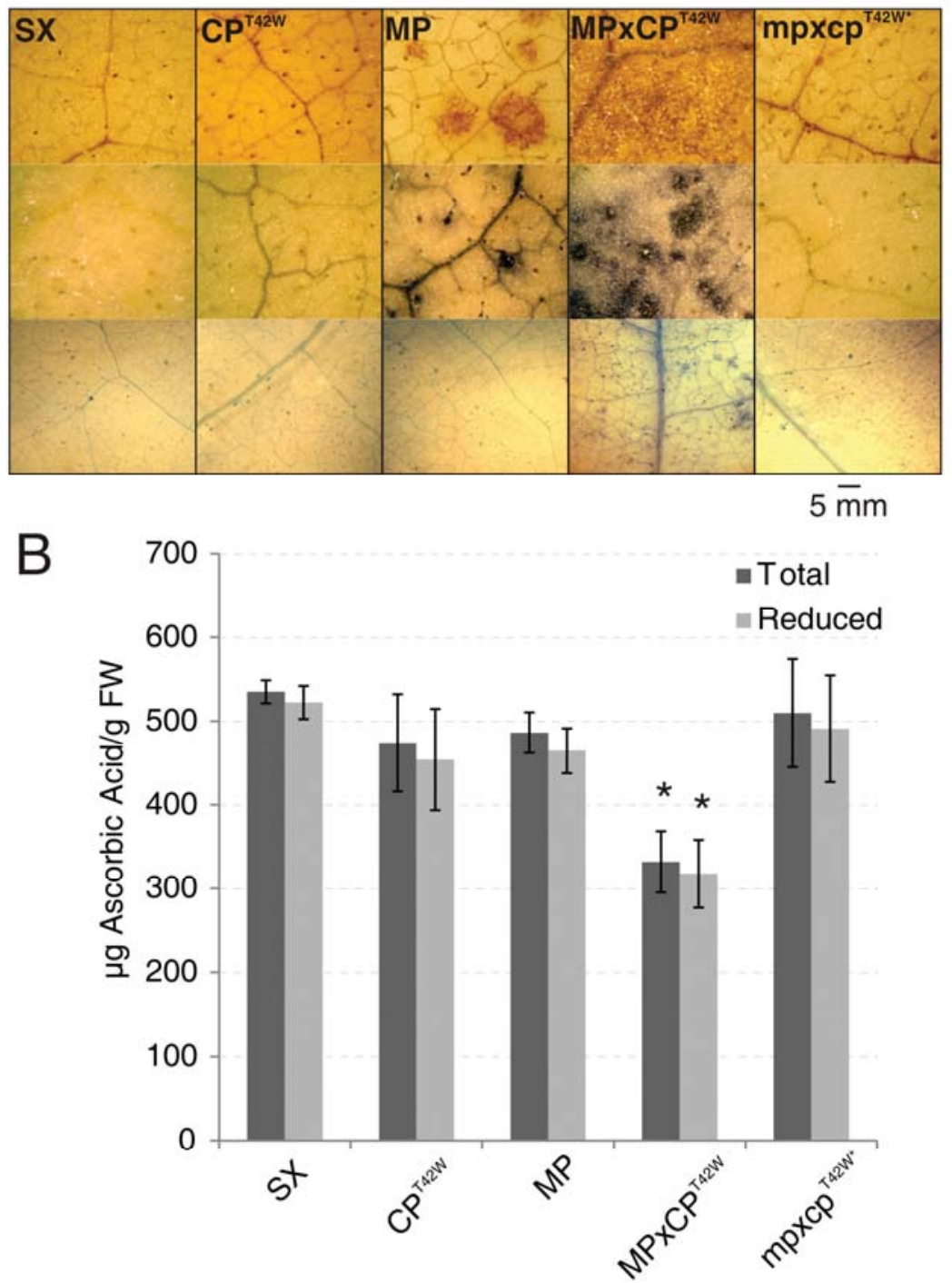
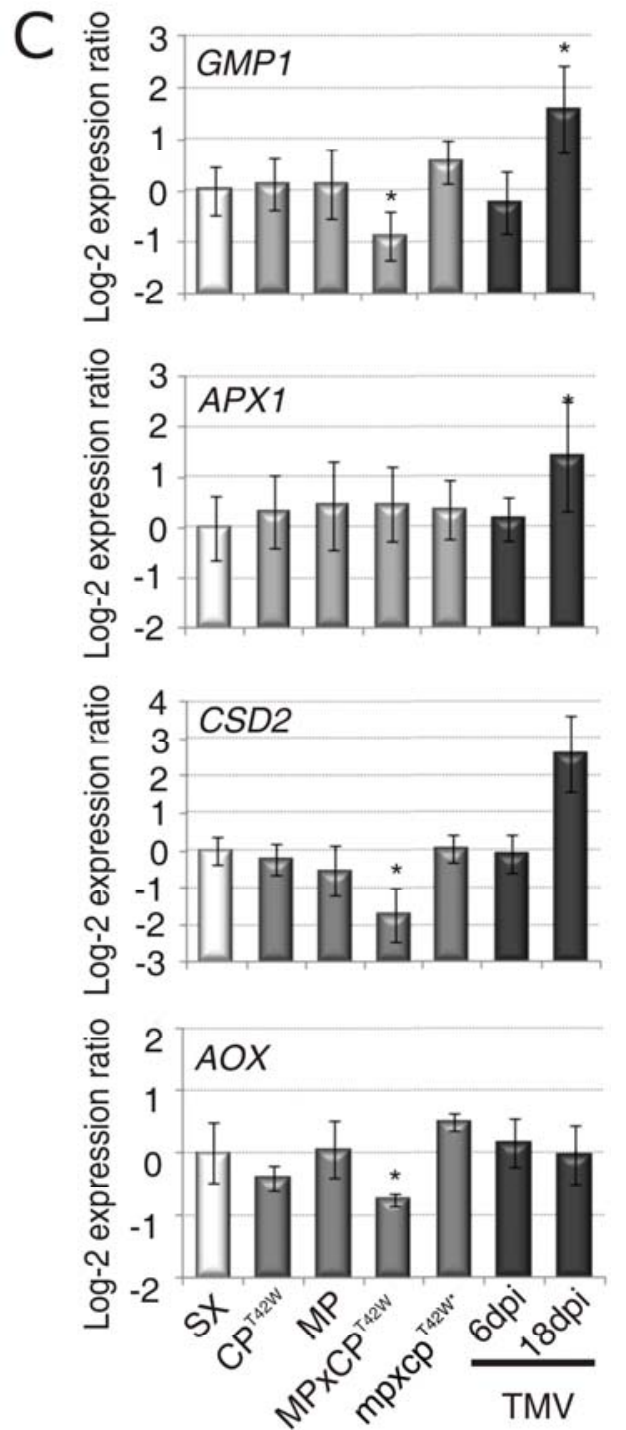

Fig. 2. Characterization of the stress-like phenotypes. A, Histochemical staining of leaf tissues from transgenic plants (variant of Tobacco mosaic virus [TMV] coat protein $\left[\mathrm{CP}^{\mathrm{T} 42 \mathrm{~W}}\right]$, movement protein [MP], a hybrid line coexpressing both [MP $\times \mathrm{CP}^{\mathrm{T} 42 \mathrm{~W}}$, and the silenced control [mp $\times \mathrm{cp}^{\mathrm{T} 42 \mathrm{~W}}$ ]) and wild-type controls (SX). The first line corresponds to diaminobenzidine staining for detection of $\mathrm{H}_{2} \mathrm{O}_{2}$, the second one to nitroblue tretrazolium staining for $\mathrm{O}_{2}^{-}$, and the third one provides evidence of cell death visualized with trypan blue. B, Total (ascorbic [ASC] and dehydroascorbic [DHA] acid) and reduced ascorbic acid determination by high-performance liquid chromatography. C, Relative transcript levels of GDP-mannose pyrophosphorylase 1 (GMP1), cytosolic ascorbate peroxidase (cAPX1), chloroplast superoxide dismutase 2 (CSD2), and alternative oxidase (AOX) in transgenic tobaccos as indicated, in wild-type SX controls, and in TMV-infected plants at 6 and 18 days postinfection (dpi), determined by reverse-transcriptase quantitative polymerase chain reaction. Bars represent the relative transcript level \pm standard error of five replicates. Asterisks indicate significant differences between transgenic plants, compared with the wild-type SX (* and ** indicate $P$ values $<0.05$ and 0.01 , respectively). 
pressing $\mathrm{MP} \times \mathrm{CP}^{\mathrm{T} 42 \mathrm{~W}}$ plants (Fig. 3A). As a second strategy, we performed RT-qPCR to evaluate the expression levels of SA-responsive genes PR-1 (SGN-U444943), PR-2 (SGNU439941), and PR-5 (SGN-U446829). In agreement with the
SA level observed (Fig. 3A), all of these genes were upregulated in MP and $\mathrm{MP} \times \mathrm{CP}^{\mathrm{T} 42 \mathrm{~W}}$ plants (Fig. 3B), and no increase was detected in the silenced control mpxcp ${ }^{\mathrm{T} 42 \mathrm{~W} *}$ line. Unexpectedly, a reduction in PR-1 transcripts was found in $\mathrm{CP}^{\mathrm{T} 42 \mathrm{~W}}$
A
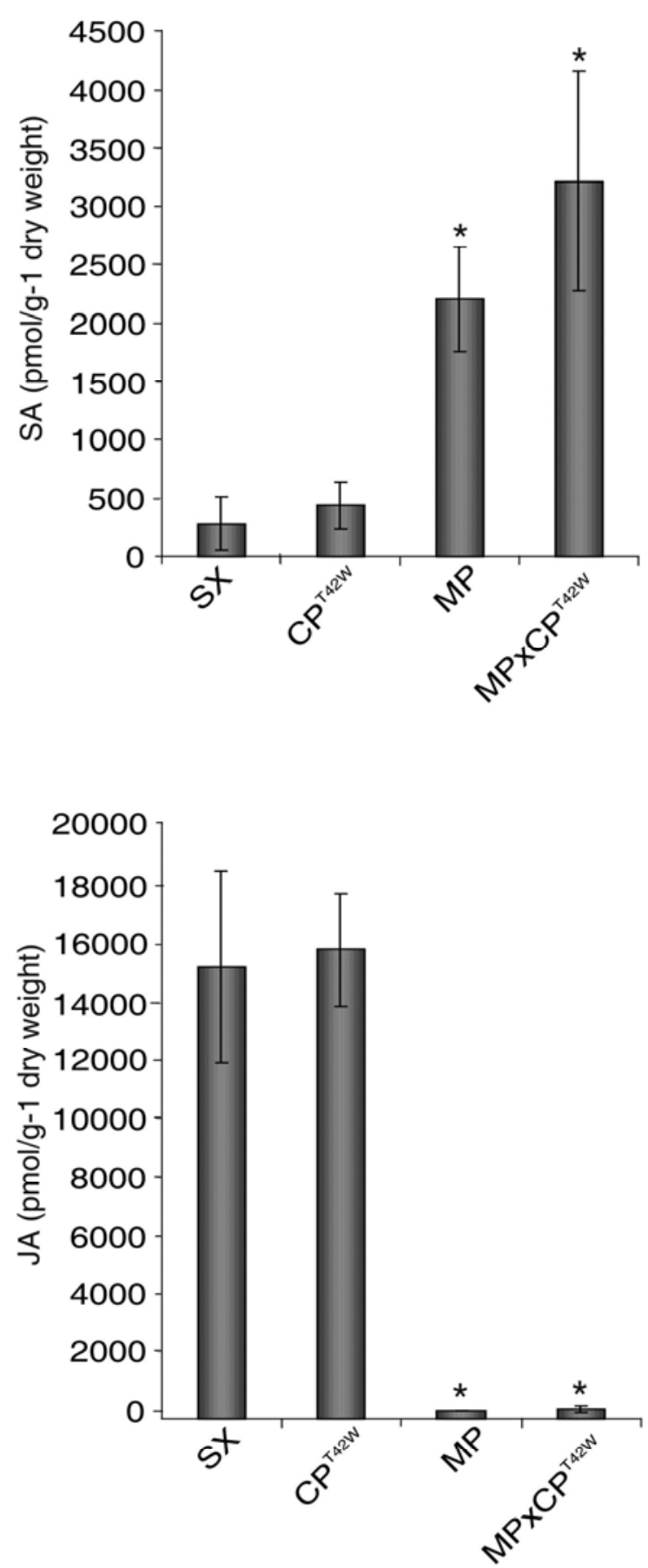
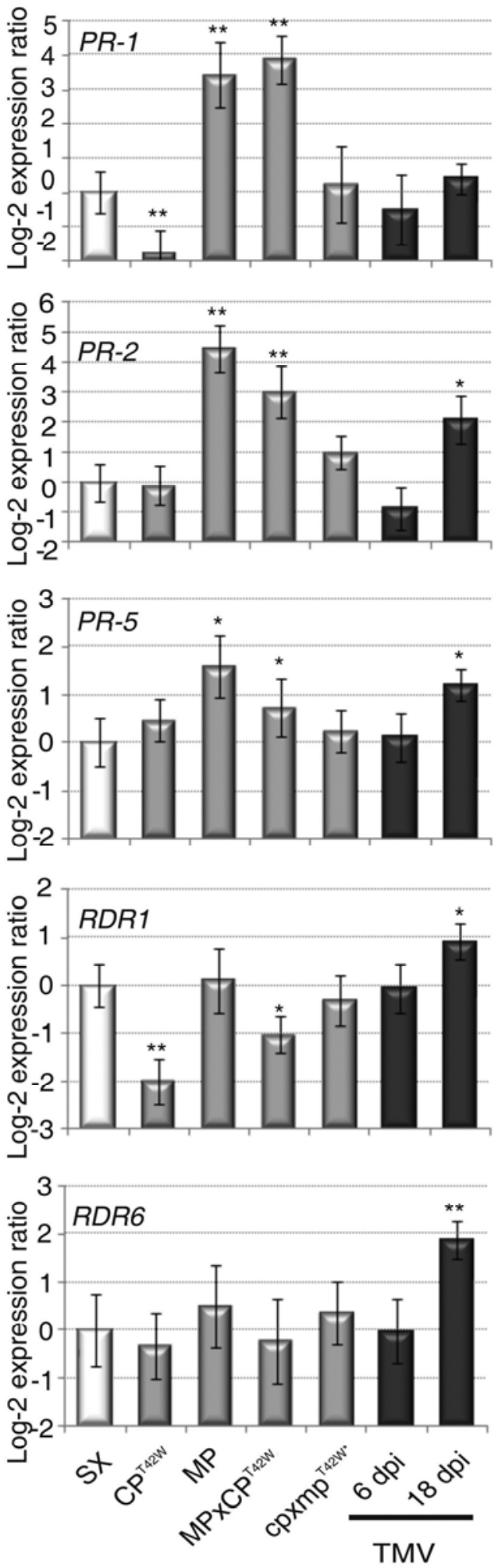

Fig. 3. Characterization of defense-like phenotypes. A, Salicylic acid (SA) and jasmonic acid (JA) levels determined by high-performance liquid chromatography in transgenic lines of a variant of Tobacco mosaic virus (TMV) coat protein ( $\mathrm{CP}^{\mathrm{T} 42 \mathrm{~W}}$ ), movement protein (MP), and a hybrid line coexpressing both $\left(\mathrm{MP} \times \mathrm{CP}^{\mathrm{T} 42 \mathrm{~W}}\right.$ ) compared with wild-type control plants (SX). B, Relative expression levels of SA-responsive genes $P R-1, P R-2$, and $P R-5$ and genes responsible for silencing defense against viral RNAs, RDR1, and RDR6 in transgenic tobaccos and wild-type SX controls, $\mathrm{CP}^{\mathrm{T} 42 \mathrm{~W}}, \mathrm{MP}, \mathrm{MP} \times \mathrm{CP}^{\mathrm{T} 42 \mathrm{~W}}$, the silenced control $\left(\mathrm{mp} \times \mathrm{cp}^{\mathrm{T} 42 \mathrm{~W}^{*}}\right)$ and TMV-infected plants at 6 and 18 days postinfection (dpi), determined by reverse-transcriptase quantitative polymerase chain reaction. The mean relative transcript level \pm standard error of five replicates is shown. Asterisks indicate significant differences between transgenic plants, compared with the wild-type SX (* and ** indicate $P$ values $<0.05$ and 0.01 , respectively). 
plants. The induction of most of the SA-responsive tested transcripts was also observed in TMV-infected plants at $18 \mathrm{dpi}$.

RDRl (referred to as NtRdRPl) (SGN-U431860), a SAresponsive gene directly involved in RNAi defense against vi- ruses (Xie et al. 2001), was upregulated in TMV-infected plants at $18 \mathrm{dpi}$ but, surprisingly, it was reduced in $\mathrm{CP}^{\mathrm{T} 42 \mathrm{~W}}$ and $\mathrm{MP} \times \mathrm{CP}^{\mathrm{T} 42 \mathrm{~W}}$ lines. Additionally, we found that transgenic viral protein expression did not alter RDR-6 (SGN-U437134) ex-
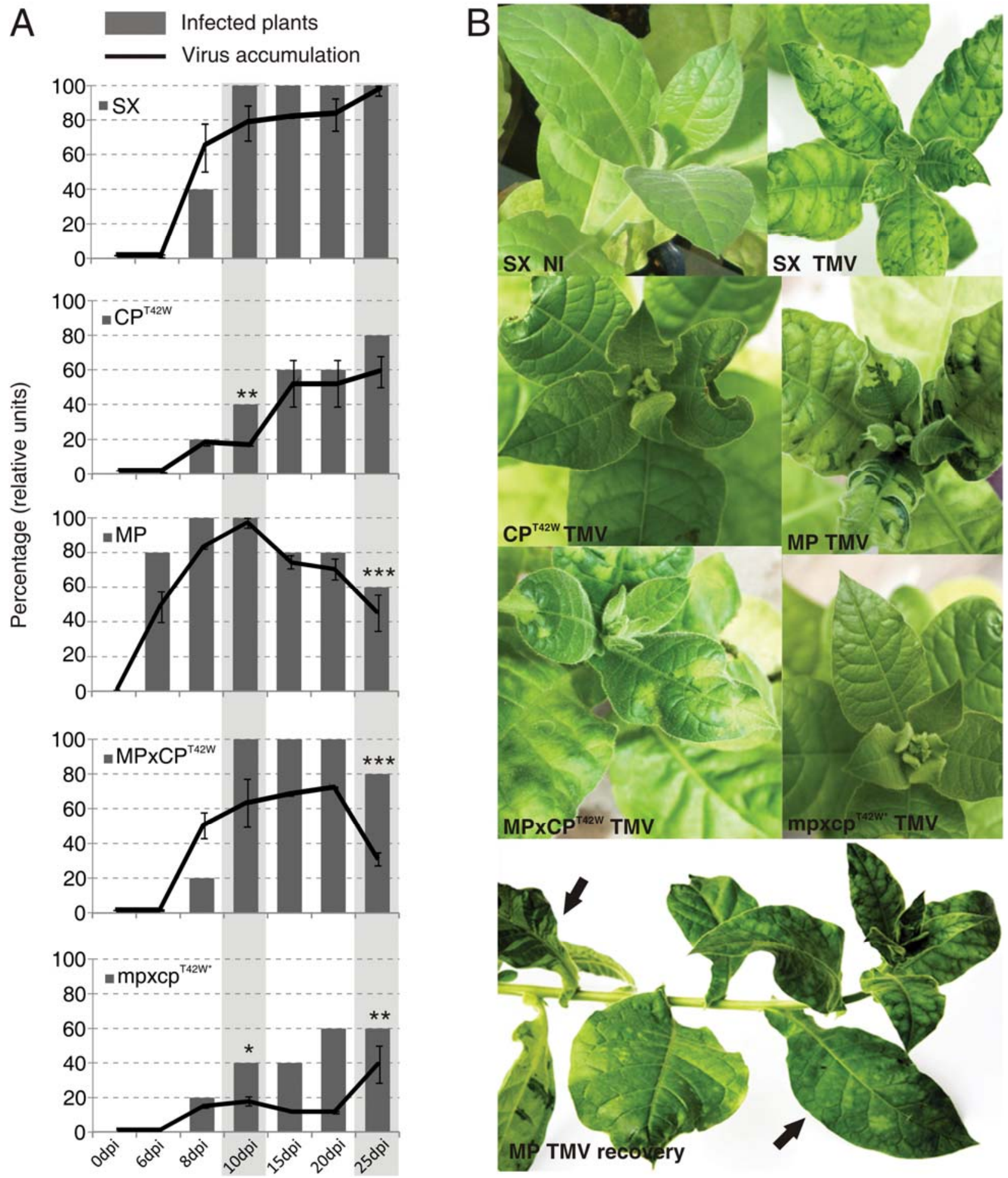

Fig. 4. Effects of Tobacco mosaic virus (TMV) RNA infection. A, Bar graphs show the percentage of TMV-infected plants (enzyme-linked immunosorbent assay [ELISA] positive) during the infection time course. Line graphs show the accumulation level of coat protein (CP) (mean values \pm standard error of eight replicates per plant line) quantified by ELISA for samples collected at 0, 6, 8, 10, 15, 20, and 25 days postinfection (dpi). Gray shadow boxes highlight the time point were statistical analysis is shown, comparing viral accumulation levels between transgenic plant lines and SX controls. Asterisks indicate significant differences between transgenic plants compared with the wild-type SX (*, **, and *** indicate $P$ values $<0.05,0.01$, and 0.005 , respectively). Data shown are from a representative assay of three independent replicates. B, Differential symptoms displayed by all the transgenic plant lines and wild-type control plants (SX) at $10 \mathrm{dpi}$ as indicated in the figure and recovery-like phenotype observed in 25 dpi movement protein (MP) tobacco (bottom panel). The black arrow on the left indicates a leaf with severe TMV-symptoms and the right arrow shows a leaf with mild symptoms demonstrating the recovery phenotype. Similar results were obtained in three independent assays. 
pression, another antiviral gene implicated in post-transcription gene silencing (Curaba and Chen 2008), but TMV systemic infection did induce its expression.

Altogether, these results suggest that the MP behaves as a defense elicitor inducing a defense signal mediated by SA. In agreement with the stress-like response observed in Figure 2, it seems that the constitutive expression of MP triggers defenselike responses. A similar but stronger effect was demonstrated in $\mathrm{MP} \times \mathrm{CP}^{\mathrm{T} 42 \mathrm{~W}}$ coexpressing plants. However, the diminishing effect of $\mathrm{CP}^{\mathrm{T} 42 \mathrm{~W}}$ on the PR-1 and RDR-1 expression levels suggests a role for this viral protein as a negative modulator of specific defense-like responses.

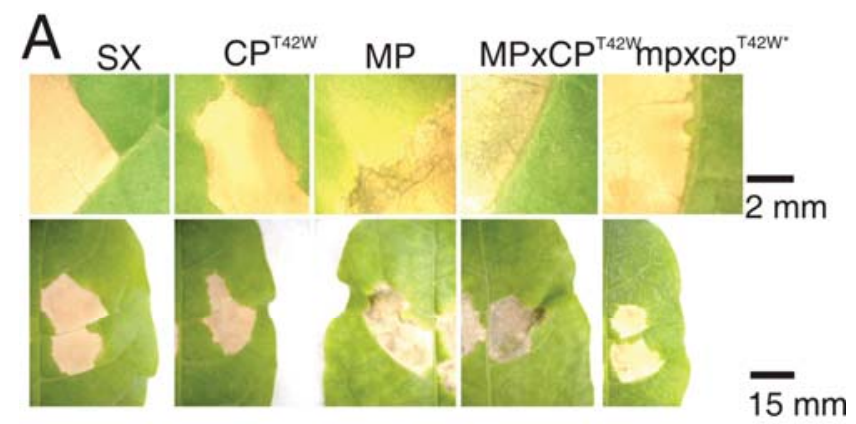

B
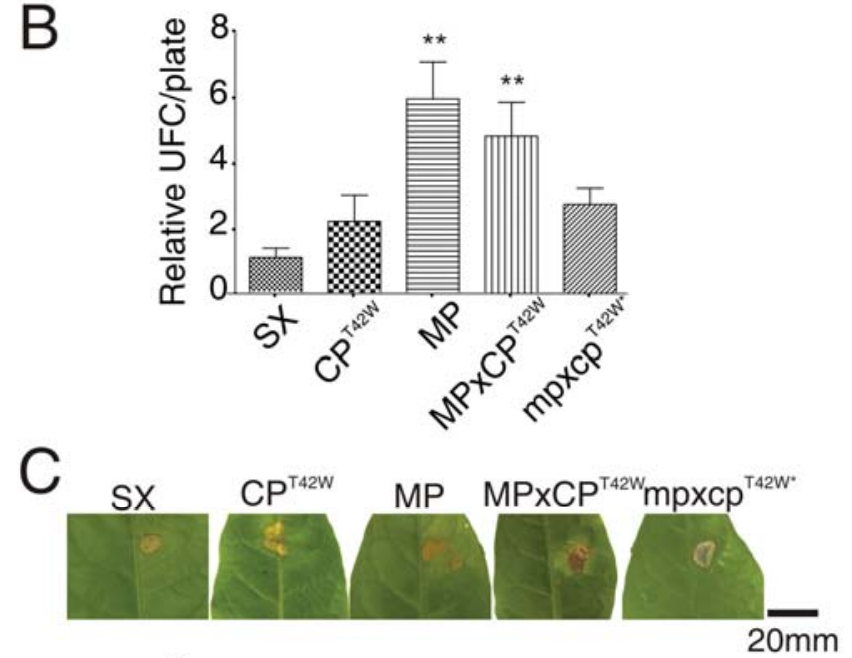

D

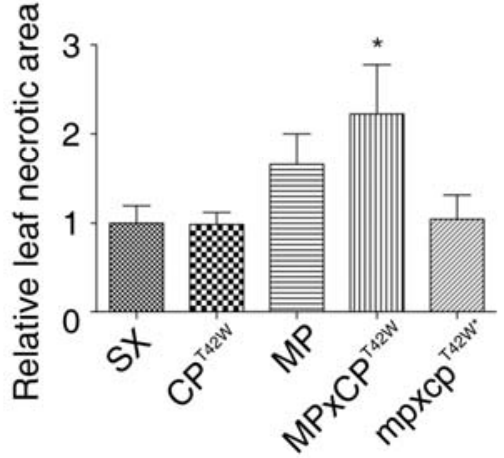

Fig. 5. Effects of Pseudomonas syringae pv. tabaci and Sclerotinia sclerotiorum infection. A, $P$. syringae necrotic lesions observed in transgenic lines and wild-type tobacco leaf tissues at $48 \mathrm{~h}$ postinoculation (hpi). B, Mean UFC/plate relative bacterial count values \pm standard error in samples (leaf discs) collected from 8 plants per line 48 hpi. Statistical differences are shown by $* *$, indicating $P<0.01$. Similar results were obtained in two independent repetitions of the experiment. C, S. sclerotiorum necrotic lesions observed 6 days postinoculation. D, Relative quantification of leaf necrotic area in 10 leaves per transgenic line and SX controls. Statistical differences between leaf necrotic areas are shown by $*$, indicating $P<$ 0.05 . Similar results were obtained in two independent repetitions of the experiment.
Transgenic expression of MP promotes a recovery-like phenotype in infections with TMV RNA.

The changes of the stress and defense responses produced in the transgenic lines could alter the course of a pathogen infection. To test the effects of TMV CP and MP coexpression on the infectivity of plant viruses, each transgenic line and the wildtype control SX were inoculated with TMV RNA that is not affected by CP-MR. The virus accumulation in the systemic tissue was verified by enzyme-linked immunosorbent assay (ELISA) at different time points upon inoculation $(6,8,10,15,20$, and 25 dpi) and the progress and severity of symptoms were also monitored. (Fig. 4A and B.). All wild-type SX plants showed virus accumulation at $10 \mathrm{dpi}$ and displayed the highest virus accumulation level at $25 \mathrm{dpi}$. As expected, the $\mathrm{CP}^{\mathrm{T} 42 \mathrm{~W}}$ transgenic line showed an initial mild resistance to TMV RNA (Bazzini et al. 2007), showing statistically significant lower accumulation at 10 dpi. However, at $25 \mathrm{dpi}, 80 \%$ of the inoculated plants became infected, reaching a moderate viral accumulation and milder symptoms. In turn, the $m p \times c p^{\mathrm{T} 42 \mathrm{~W} *}$ line was highly resistant: only $60 \%$ of the plants showed detectable virus at late stages, presenting statistically low virus accumulation and almost no symptoms at $25 \mathrm{dpi}$. Interestingly, despite the expression of $\mathrm{CP}^{\mathrm{T} 42 \mathrm{~W}}, \mathrm{MP} \times \mathrm{CP}^{\mathrm{T} 42 \mathrm{~W}}$ plants were susceptible to TMV RNA infection, and $100 \%$ of the plants were infected and showed viral titles similar to SX controls until approximately $10 \mathrm{dpi}$. At late stages ( $25 \mathrm{dpi}$ ), there was a significant decrease in virus accumulation and fewer plants showed detectable levels of virus, demonstrating a partial recovery on systemic viral infection accompanied by a reduction in disease symptoms (Fig. 4A, gray shadow boxes). A similar effect was observed in the MP plant line, which showed even higher susceptibility than SX controls at early stages (until $10 \mathrm{dpi}$ ), reaching a total of $80 \%$ of the plants with detectable virus at $6 \mathrm{dpi}$ and the highest virus accumulation at $10 \mathrm{dpi}$. At late stages (25 dpi), MP-infected plants showed a strong recovery process, as indicated by a reduction from 100 to $60 \%$ of the plants with detectable virus accompanied by significantly lower virus accumulation (Fig. 4A, gray shadow boxes) in the infected tissue. In summary, $\mathrm{MP} \times \mathrm{CP}^{\mathrm{T} 42 \mathrm{~W}}$ and MP plant lines are somehow more susceptible to TMV RNA at early stages of infection and more resistant in late stages because of partial recovery and symptom-shifting.

\section{MP expression and coexpression}

\section{of $\mathrm{MP}$ and $\mathrm{CP}^{\mathrm{T} 42 \mathrm{~W}}$ enhance susceptibility}

to hemibiotrophic and necrotrophic pathogens.

Inoculations with hemibiotrophic Pseudomonas syringae pv. tabaci and necrotrophic fungus Sclerotinia sclerotiorum were performed as an attempt to examine the effect of TMV CP and MP on the infectivity of pathogens with diverse lifestyles and with differences on the defense pathway induction. Leaves infiltrated with $P$. syringae pv. tabaci developed necrotic lesions in all plant lines and wild-type controls; however, the lesions observed in MP and $\mathrm{MP} \times \mathrm{CP}^{\mathrm{T} 42 \mathrm{~W}}$ plants were more severe (Fig. 5A). After 48 h, leaf discs from infected tissue were collected and incubated in King's B medium. Plate count showed higher bacterial growth rates in $\mathrm{MP}$ and $\mathrm{MP} \times \mathrm{CP}^{\mathrm{T} 42 \mathrm{~W}}$ transgenic plants (Fig. 5B). Differences in the development of disease symptoms caused by $S$. sclerotiorum were also observed (Fig. 5C). The average necrotic lesion size in infected leaves of control and transgenic lines was measured. In agreement with results observed with $P$. syringae infection, $\mathrm{MP} \times \mathrm{CP}^{\mathrm{T} 42 \mathrm{~W}}$ transgenic lines showed statistically significant wider necrotic lesions 6 days after $S$. sclerotiorum inoculation and MP lines showed a similar but not significant tendency (Fig. 5D). Taken together, these results showed that MP and $\mathrm{MP} \times \mathrm{CP}^{\mathrm{T} 42 \mathrm{~W}}$ transgenic lines had an enhanced susceptibility to P. syringae pv. tabaci and S. sclerotiorum. 
The silencing of GMP1 produced stress-like responses similar to those from the $\mathrm{MP} \times \mathrm{CP}^{\mathrm{T} 42 \mathrm{~W}}$ phenotype and enhanced resistance against TMV infections in $N$. benthamiana.

According to data from the expression profile and RT-qPCR ratios, GMP1 was downregulated in $\mathrm{MP} \times \mathrm{CP}^{\mathrm{T} 42 \mathrm{~W}}$ plants. Ascorbic acid contents were significantly reduced in these plants (Fig. 2B). As previously reported, the Arabidopsis vtc-1 mutant (knock-down mutant of GMP1) is deficient in ascorbic acid content, has a retarded growth and flowering (Conklin et al. 2000; Pastori et al. 2003), accumulates high ROS, exhibits increased cell death rates and elevated SA levels, induces PR-1 and PR-5 expression, and has an enhanced basal resistance against $P$. syringae infection (Colville and Smirnoff 2008; Mukherjee et al. 2010; Pavet et al. 2005). Taking all these findings into account, we explored in detail a possible involvement of GMP1 in the stress and defense responses observed in $\mathrm{MP} \times \mathrm{CP}^{\mathrm{T} 42 \mathrm{~W}}$ plants. To analyze this putative effect, a Tobacco rattle virus (TRV)-based virus-induced gene silencing (VIGS) system was employed for mimicking GMP1 downregulation in transgenic $\mathrm{MP} \times \mathrm{CP}^{\mathrm{T} 42 \mathrm{~W}}$ plants. pTRV2-gmp1, carrying a partial $N$. tabacum GMP1 sequence (506 bp), and pTRV-gfp controls were infiltrated in $N$. benthamiana plants and systemic GMP1 silencing was confirmed by RT-qPCR (Fig. 6A). The gmplsilenced plants dramatically reduced growth and showed higher ROS levels, detected in the leaf tissue by staining with DAB and NBT (Fig. 6B and C). These results confirmed that GMP1 plays an important role in the ROS scavenging system of $N$. benthamiana and suggested that GMP1 could be part of the stress-like phenotype observed in $\mathrm{MP} \times \mathrm{CP}^{\mathrm{T} 42 \mathrm{~W}}$ plants. When gmpl-silenced $N$. benthamiana plants were infected with TMV, an enhanced resistance was observed at late stages of infection (15 dpi) (Fig. 6D and E). This effect could be somehow parallel to that observed in MP and $\mathrm{MP} \times \mathrm{CP}^{\mathrm{T} 42 \mathrm{~W}}$ plant lines when infected with TMV RNA. Additionally, we observed similar results in the accumulation level of defense and stress response genes given by an increased accumulation of PR-1 and decreased levels of CSD2 (Fig. 6F). Increased tolerance against a low inoculum of the tobamovirus Oiled-raped mosaic virus (ORMV) was also displayed in 6-week-old Arabidopsis $v t c 1$-mutants (Figs. 6G and $\mathrm{H}$ ). Therefore, gmpl silencing in both $N$. benthamiana and Arabidopsis vtcl mutants displayed an enhanced resistance to viral infections, which indicates that the earlier triggering of the defense response mediated by ROS produces an increased resistance in the plants.

\section{DISCUSSION}

A rapid viral replication in plant tissues involves the synthesis of large amounts of virus nucleic acids and proteins that must redirect host resources from normal cellular processes toward this viral replication process. It has already been reported that host demands can be modified by the virus through the specific downregulation of cellular gene expression (Aranda and Maule 1998). The effect, called host gene shut off, compromises some aspects of plant physiology and broad-spectrum defense response (Bazzini et al. 2011; Havelda and Maule 2000; Maule et al. 2002; Pallas and Garcia 2011). Shut off has been described as a transient effect developed within the virus replication cycle. However, Havelda and associates (2008) have demonstrated that viruses from some RNA virus families induce host gene transcript downregulation not directly in association with active viral replication. Furthermore, they have observed that the phenomenon persists for several weeks. In this study, we demonstrated that the stable transgenic coexpression of TMV $\mathrm{CP}^{\mathrm{T} 42 \mathrm{~W}}$ and MP could induce a gene-specific and persistent shut-off phenomenon. This effect is independent from viral replication and the depletion of host resources that occur during a systemic TMV infection, as evidenced by the insignificant accumulation of transgenic viral nucleic acids and proteins when compared with the protein level reached by the infection itself (Bazzini et al. 2007).

As clearly demonstrated by transcript profiling (microarray analysis and RT-qPCR), some genes required for ROS scavenging and defense signaling were downregulated in $\mathrm{MP} \times \mathrm{CP}^{\mathrm{T} 42 \mathrm{~W}}$. It has been well documented that ROS are important in plant adaptation to both biotic and abiotic stresses (Apel and Hirt 2004; Mittler 2002). Under these conditions, ROS may play different roles. For example, they could be exacerbating damage or activating defense response signaling (Dat et al. 2000; Mittler et al. 2011). Consequently, the concentration of ROS has to be tightly regulated to maintain cell homeostasis. During compatible Cucumis sativus-Cucumber mosaic virus and Cucurbita pepo-Zucchini yellow mosaic virus interactions, plants displayed enhanced antioxidant capacities and inhibited local cell death by inducing superoxide dismutases, catalases, and ascorbate peroxidases, among others (Riedle-Bauer 2000). However, total ascorbate content and activities of scavenging enzymes were slightly and transiently reduced in TMV-inoculated leaves of $N$. tabacum before hypersensitive response (Fodor et al. 1997; Mittler et al. 1998; Yi et al. 1999). Thus, the suppression of the antioxidant system is important for local PCD induction in hypersensitive responses developed after localized pathogen recognition (Dat et al. 2003; Lorrain et al. 2003; Mittler et al. 1999; Yi et al. 2003). Immediately, compensatory mechanisms must necessarily be activated to stop PCD signaling and to maintain ROS formation (Bajda et al. 2009; Liao et al. 2012). These data are in agreement with our results, which showed that elevated transcript levels of cAPX1, CSD2, and GMP1 were produced in TMV-infected tobaccos at 18 dpi. Interestingly, we observed generalized and systemic decreases in total ascorbic acid content and reductions of GMP1, CSD2, and AOX transcript levels as a consequence of $\mathrm{CP}^{\mathrm{T} 42 \mathrm{~W}}$ and $\mathrm{MP}$ coexpression. In addition, the transcript levels of cAPX1 were unchanged in MP and $\mathrm{MP} \times \mathrm{CP}^{\mathrm{T} 42 \mathrm{~W}}$ plant lines. Altogether, these effects resulted in an enhanced stress response phenotype given by a high accumulation of ROS. Compensatory mechanisms to suppress toxic ROS levels were not activated, resulting in a strong ROS accumulation that could lead to the production of $\mathrm{PCD}$ micro-focuses in the $\mathrm{MP} \times \mathrm{CP}^{\mathrm{T}} 42 \mathrm{~W}$ transgenic line. Moreover, this line showed reduced growth and defective development (Bazzini et al. 2007). The downregulation of the transcription of scavenging enzyme genes could be mediated by the enhancement of MP function on the complex formed by $\mathrm{MP}$ and $\mathrm{CP}^{\mathrm{T} 42 \mathrm{~W}}$ (Asurmendi et al. 2004; Bazzini et al. 2007). A similar effect has been observed in pea plants inoculated with Plum pox virus (PPV) (Diaz-Vivancos et al. 2008). At 3 dpi, no changes were detected in the oxidative stress parameters, whereas decreases in chloroplast enzymatic mechanisms (ascorbate peroxidase and peroxidase) resulted in increased levels of $\mathrm{H}_{2} \mathrm{O}_{2}$ in this compartment. The stress response was higher at $15 \mathrm{dpi}$, as judged from exacerbated stress parameters and imbalances detected in the antioxidant system. However, the modulation of the expression of detoxifying and antioxidant enzymes has been shown to enhance basal defense against pathogens (Barth et al. 2004; Mittler et al. 1999; Pavet et al. 2005) and to induce the expression of plant defense proteins (Pastori et al. 2003; Pnueli et al. 2003).

There are additional regulatory functions for ROS in defense that may occur in conjunction with other signaling molecules, particularly with SA (Alvarez 2000; Durrant and Dong 2004). It has already been demonstrated that, in resistance-genemediated TMV-resistant tobacco plants, SA levels increase more than 20 -fold in the inoculated leaves and approximately fivefold 

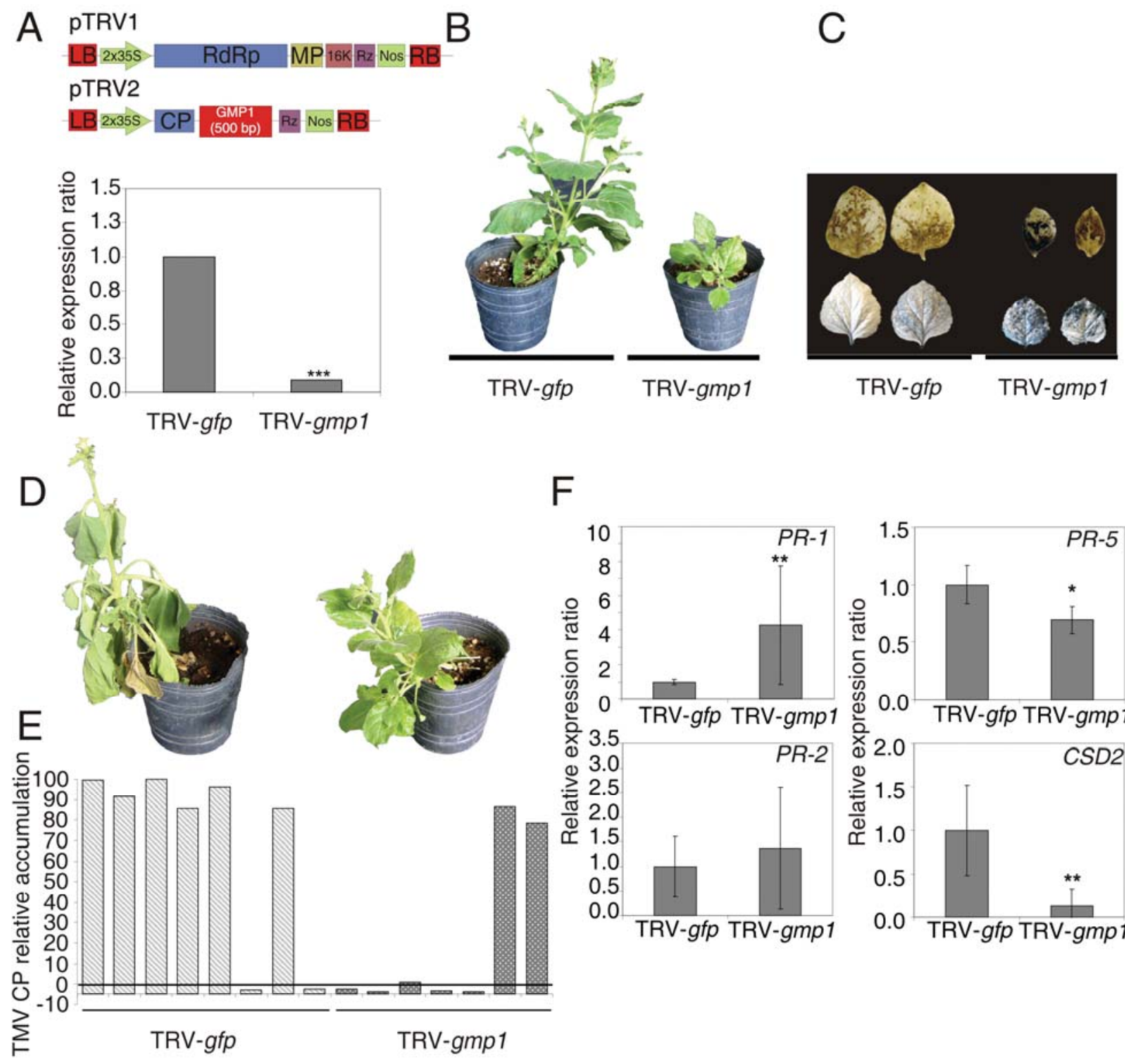

$\mathrm{F}$
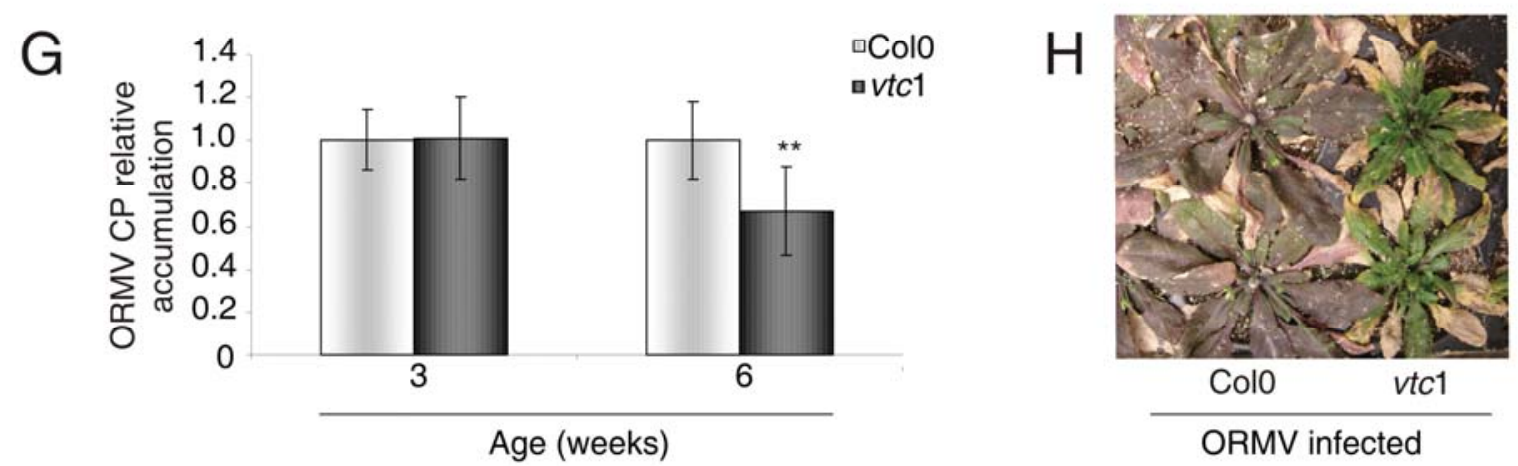

Fig. 6. Effects of the GDP-mannose pyrophosphorylase 1 (GMP1) silencing on development, stress, and defense responses in Nicotiana benthamiana. A, Scheme of pTRV1 and pTRV2-gmp1 constructs used for Tobacco rattle virus (TRV) infection by agroinfiltration and reverse-transcriptase quantitative polymerase chain reaction (RT-qPCR) verification of GMP1 silencing 2 weeks after virus-induced gene silencing (VIGS). B, Effects of GMP1 silencing on plant growth and development 2 weeks after inoculation. C, Diaminobenzidine and nitroblue tretrazolium staining of GMP1-silenced leaves versus TRVgreen fluorescent protein ( $g f p$ ) control leaves. D, Differential symptom development of TRV-gfp control (left) and TRV-gmpl-silenced (right) plants inoculated with TMV at 10 days postinfection (dpi). E, Bar graphs showing relative levels of TMV coat protein (CP) accumulation in individual TRV-gfp control and TRV-gmp1 plants as determined by enzyme-linked immunosorbent assay (ELISA) test. F, Effects of GMP1 silencing on relative expression levels of salicylic-acid-responsive genes pathogenesis-related (PR)-1, PR-2, and PR-5 and detoxifying chloroplast superoxide dismutase 2 (CSD2) in TRVgmpl and TRV-gfp plants determined by RT-qPCR 2 weeks after inoculation. The mean relative transcript level \pm standard error of five replicates is shown. Asterisks indicate significant differences $(*$ and $* *$ indicate $P$ values $<0.05$ and 0.01 , respectively). G, Mean relative accumulation levels of Oiled-raped mosaic virus (ORMV) CP (as determined by ELISA test) in 3- and 6-week-old vtc1-Arabidopsis mutants and Col0 controls at 7 dpi. Mean values were obtained from 10 plants per treatment. H, Differential symptom severity in 6-week-old vtc1-Arabidopsis mutants and Col0 control plants inoculated with ORMV at 7 dpi. Statistical differences are shown by *,**, and ***, indicating $P$ values $<0.05,0.01$, and 0.005 , respectively. 
in the systemic leaves. In addition, PR gene expression is also induced in these plants (Malamy et al. 1990). Interestingly, treatment of susceptible tobacco with SA causes a profound reduction in TMV accumulation. This effect occurs with no macroscopically visible cell death, and associated with ROS mediated signaling (Chivasa et al. 1997; Urbanek Krajnc et al. 2011). Enhanced levels of SA and decreased levels of JA were observed in all transgenic plant lines that overexpress MP, which suggests that at least this viral protein is sufficient to modulate the stress and defense responses in tobacco plants. In addition, it has been proposed that PR-1 proteins are not involved in transgenic ${ }^{\mathrm{TMV}} \mathrm{CP}-$ mediated resistance mechanism (Carr et al. 1989). Our findings demonstrated that a mutated version of $\mathrm{CP}\left(\mathrm{CP}^{\mathrm{T} 42 \mathrm{~W}}\right)$ downregulates $\mathrm{PR}-1$ and $\mathrm{RDR}-1$ in transgenic plants. This effect is evident in $\mathrm{MP} \times \mathrm{CP}^{\mathrm{T} 42 \mathrm{~W}}$ for RDR-1 expression but not for PR-1. Therefore, $\mathrm{CP}^{\mathrm{T} 42 \mathrm{~W}}$ could be acting as a negative modulator of specific host defenses. This response is different from that elicited by MP expression; however, both responses could be derived from similar shut-off mechanisms with differential gene specificity for each viral protein.

The negative effect on defense activation described for $\mathrm{CP}^{\mathrm{T} 42 \mathrm{~W}}$ is in agreement with the reported abilities of CP to suppress or evade some plant responses by interacting with host factors (Callaway et al. 2001). Moreover, TMV CP facilitates TMV systemic movement by specifically interacting with a host component in N. tabacum (Hilf and Dawson 1993). Therefore, a tempting interpretation of our results point toward a role for the CP-mediated downregulation phenomenon of defense genes in the systemic viral movement.

The initial response triggered by TMV RNA infection in MP and $\mathrm{MP} \times \mathrm{CP}^{\mathrm{T} 42 \mathrm{~W}}$ lines is characterized by a rapid and systemic spread of the virus and also by an accelerated progression of symptoms. This first stage of the infection is followed by a recovery stage with a conspicuous reduction of both TMV accumulation and symptoms in systemic tissue. In addition, $\mathrm{MP} \times \mathrm{CP}^{\mathrm{T} 42 \mathrm{~W}}$ plants showed slightly reduced virus accumulation, which probably demonstrates a balance between rapid virus spread owing to a direct MP activity and a delay in virus systemic accumulation given by $\mathrm{CP}^{\mathrm{T} 42 \mathrm{~W}}$ expression. By contrast, control plants exhibited a sustained increase in TMV accumulation and symptom development. We hypothesize that the first stage (in which virus accumulates faster than in nontransgenic plants) could be produced by an enhanced spread of TMV transcripts caused by the expression of MP which, in turn, facilitates the spread of virus, as has been previously reported (Guenoune-Gelbart et al. 2008; Niehl and Heinlein 2011). It could also be argued that the enhanced expression of $\beta$ 1-3 glucanases (PR-2) in MP-expressing lines might facilitate virus movement by degrading callose deposition in plasmodesmata (Baebler et al. 2011; Beffa et al. 1996; Epel 2009). In the second stage (in which virus accumulation decays and recovery of disease symptoms occurs), we hypothesize that the expression of MP promotes the control of the disease not only by means of enhancing the transport of the silencing signal, as has been previously proposed (Vogler et al. 2008), but also by inducing the activation of defense responses mediated by ROS and SA. Thus, the activation of basal defense responses and the enhancement of RNA-silencing given by MP transgenic expression could produce a combined effect that results in a reduced systemic viral spread and accumulation, giving rise to a partial recovery from infection. RNA-silencing and SAdependent responses are suggested to play key roles in limiting Tomato ringspot virus spread in tobacco (Jovel et al. 2011). SA has also been proposed to enhance RNA-silencing antiviral defense against PPV in tobacco; accordingly, suppressors of gene silencing such as P1/HC-Pro would interfere with SA- mediated defense (Alamillo et al. 2006). The expression of $R D R I$ is induced by SA and in response to infection by many viruses, and it has been implicated in antiviral immunity by allowing the production of secondary small-interfering RNAs (Garcia-Ruiz et al. 2010; Xie et al. 2001). Despite all the evidence exposed that shows a connection between induction of RDR-1 and defense response mediated by SA, other mechanisms could be involved, as demonstrated in this work. For instance, our findings showed that the MP transgenic line did not induce RDR-1 expression and the $\mathrm{MP} \times \mathrm{CP}^{\mathrm{T} 42 \mathrm{~W}}$ line displayed a reduced RDR-1 transcript accumulation.

Plants trigger distinct defense responses depending on the lifestyle of the pathogen encountered. SA mainly induces defense against biotrophic pathogens that reproduce in live host cells, whereas JA acts mainly against necrotrophic pathogens that require killing host cells to grow and reproduce. Crosstalk between these defense pathways has been demonstrated to be essential to optimize the response against pathogens. Here, we showed that the expression of MP and the coexpression of $\mathrm{MP}$ and $\mathrm{CP}^{\mathrm{T} 42 \mathrm{~W}}$ result in enhanced susceptibility against $P$. syringae pv. tabaci and $S$. sclerotiorum infections. $P$. syringae pv. tabaci is a hemibiotrophic pathogen, with an initial biotrophic phase during which the infection is established, followed by a necrotrophic phase during which the pathogen completes its life cycle. Necrotrophic phases require production of large quantities of ROS and $\mathrm{H}_{2} \mathrm{O}_{2}$ for successful infections (Able 2003). In addition, necrotrophic pathogens such as $S$. sclerotiorum or Botrytis cinerea trigger hypersensitive cell death to facilitate Arabidopsis colonization (Govrin and Levine 2000). The enhanced susceptibility shown by MP and $\mathrm{MP} \times \mathrm{CP}^{\mathrm{T} 42 \mathrm{~W}}$ transgenic lines could be produced because both pathogens encountered an environment of high ROS accumulation that enabled them to initiate a necrotrophic phase. Another possibility could be that this accentuated susceptibility would be mediated by the activation of the SA-dependent response that is probably antagonistic to the specific response required for those particular pathogens. Similarly, Faize and associates (2011) have demonstrated that the overexpression of cytosolic $\mathrm{Cu} / \mathrm{Zn}$-superoxide dismutase and ascorbate peroxidase increase tolerance against $P$. syringae pv. tabaci and Agrobacterium tumefaciens in tobacco plants.

Finally, to gain a better insight into the mechanisms underlying the stress and defense outcomes in MP and $\mathrm{MP} \times \mathrm{CP}^{\mathrm{T} 42 \mathrm{~W}}$ transgenic lines, we analyzed the role played by GMP1 using a functional approach. This gene was not induced, although there were an ROS level increase in the MP plant line and it was reduced in the $\mathrm{MP} \times \mathrm{CP}^{\mathrm{T} 42 \mathrm{~W}}$ line. A similar phenotype, with high ROS accumulation, has already been reported in Arabidopsis vtcl mutants (Foyer et al. 2007; Mukherjee et al. 2010; Pastori et al. 2003) and in gmpl-silenced N. benthamiana. Reduced levels of GMP1 have been reported to be sufficient to enhance basal defense mediated by SA and PR protein expression in Arabidopsis thaliana (Barth et al. 2004; Pavet et al. 2005). In this study, an increased accumulation of PR proteins and an enhanced basal defense response against TMV were confirmed for gmp1-silenced $N$. benthamiana. A similar effect was observed in Arabidopsis vtcl challenged against ORMV. The defense outcome evidenced in gmpl-silenced $N$. benthamiana, Arabidopsis vtc1, $\mathrm{MP} \times \mathrm{CP}^{\mathrm{T} 42 \mathrm{~W}}$, and $\mathrm{MP}$ suggests that plants are primed for defense against Tobamovirus spp. in a GMP1-dependent manner (directly or indirectly). It is important to mention that the recovery effect (late phenotype) showed in the $\mathrm{MP} \times \mathrm{CP}^{\mathrm{T} 42 \mathrm{~W}}$ and MP lines is the one considered here related to ROS response. However, the interaction is more complex, as judged by the differences observed in defense responses triggered against $P$. syringae. Therefore, according to the results obtained, different defense mechanisms can be 
triggered from similar redox and hormone imbalances. This is in agreement with the idea exposed by Mittler and associates (2011). In their study, the authors suggest that ROS-mediated signaling possesses a specific signature (probably a set of combinatorial factors acting in parallel) that provides the specificity to trigger different responses.

In conclusion, our findings indicate that a constitutive expression of TMV CP and MP triggers specific stress and defense-like phenotypes and modulates defense responses in a complex manner. It is evident that the mechanisms underlying disease susceptibility and tolerance or resistance depend on a complex regulatory network, and viruses are able to disrupt these fine tunings. Therefore, in this study, we dissected the effect of TMV CP and MP proteins alone or in combination without considering the timing of expression involved in an infection. MP seems to act as a defense elicitor, altering ROS and SA levels, and it is the viral component responsible for enhancing susceptibility against hemibiotrophic and necrotrophic pathogens. CP seems to play a negative effect on host defense by reducing the expression level of defense transcripts like PR-1 and RDR-1. These individual effects reflect the ability of a virus to control its own virulence, given that extremely high virulence is not advantageous, because it could deplete host resources excessively fast. The more efficient viruses are those which achieved balanced behavior and can coexist with hosts without altering their physiology and development.

\section{MATERIALS AND METHODS}

\section{RNA extraction and microarray analysis.}

To detect differential gene expression between hybrid $\mathrm{MP} \times \mathrm{CP}^{\mathrm{T} 42 \mathrm{~W}_{-}}$and $\mathrm{mp} \times \mathrm{cp}^{\mathrm{T} 42 \mathrm{~W}^{*} \text {-silenced tobacco transgenic }}$ plants, a microarray analysis was performed using a Tomato 10K Affymetrix GeneChip. Leaf tissues from 6-week-old tobacco plants were collected and pools of three plants were homogenized with a mortar and pestle in liquid nitrogen. Next, total RNA was extracted with an RNeasy plant mini kit (Qiagen, Valencia, CA, U.S.A.), RNA quality was assessed with a BioAnalyzer 2100 (Agilent Technologies), and RNA concentration was determined with a spectrophotometer (Nanodrop ND1000; NanoDrop Technologies, Wilmington, DE, U.S.A.). Each microarray experiment was repeated three times with independent biological replicates (pools of three plants each) following Affymetrix's instructions manual. Raw hybridization data were preprocessed with robust multichip average (Irizarry et al. 2003). The statistical analysis of preprocessed matrix data was carried out in two phases. First, an analysis of variance (ANOVA) model was applied to keep sequences showing differences between treatments with $P$ values $<0.10$. In this way, the original matrix of 10,209 genes was reduced to 1,667. Then, a selection based on $P$ values with a cutoff of 0.05 to control FDR yielded 28 genes (Table 1). The statistical analysis was performed using InfoStat Statistical software (InfoStat Group, 2004; National University of Córdoba, Argentina). Raw data of the experiment were deposited at Gene Expression Omnibus (GSE37905).

\section{ROS accumulation and cell death detection in tobacco leaves.}

For DAB histochemical staining, leaves from control and transgenic tobacco plants were collected and were placed in 1 liter of DAB-HCl, $\mathrm{pH} 3.8$, at a rate of $1 \mathrm{mg}$ of leaf material per milliliter of $\mathrm{DAB}-\mathrm{HCl}$, as previously described (ThordalChristensen et al. 1997) (Sigma-Aldrich, Munich, Germany). For NBT staining, leaves were submerged in an NBT $0.1 \%$ solution in $50 \mathrm{mM}$ potassium phosphate buffer, $\mathrm{pH} 7.8$, as previously described by Wohlgemuth and associates (2002). Solu- tions were infiltrated into leaf tissues by 2 -min vacuum shocks in a vacuum chamber; then, the infiltrated leaf tissues were incubated overnight (for DAB staining) or for $2 \mathrm{~h}$ for NBT staining. Leaves were cleared in boiling ethanol (96\%, vol/vol) to remove chlorophyll and they were examined under a stereo light microscope. $\mathrm{H}_{2} \mathrm{O}_{2}$ was visible as a brown precipitate in the tissue and superoxide anion was detected as a blue formazan precipitate. Subsequently, for trypan blue staining, plant leaf tissues were boiled for $10 \mathrm{~min}$ in a solution composed of $10 \mathrm{ml}$ of $90 \%$ ( $\mathrm{vol} / \mathrm{vol}$ ) lactic acid, $10 \mathrm{ml}$ of $87 \%$ (vol/vol) glycerol, $10 \mathrm{ml}$ of trypan blue solution, and $10 \mathrm{~g}$ of phenol. Leaves were finally cleared with chloral hydrate $\left(2.5 \mathrm{mg} / \mathrm{ml}^{-1}\right)$, conserved in ethanol $96 \%$ (vol/vol) and examined under stereo light microscope.

\section{Real-time qPCR.}

Total RNA was isolated from 50 to $75 \mathrm{mg}$ of frozen tobacco leave tissues using Trizol Reagent (Invitrogen), quantified (NanoDrop Technologies), and treated with DNAse I (Invitrogen, Carlsbad, CA, U.S.A.). First-strand cDNA was synthesized using MMLV (Invitrogen) and random primers according to the manufacturer's instructions (Invitrogen). The oligonucleotide primer sets used for real-time qPCR analysis were designed using Primer Express 2.0 software (Applied Biosystems, Foster City, CA, U.S.A.). Experiments were carried out using four or five biological replicates in an Applied Biosystems 7500 equipment (the experimental conditions used following MIQE requirements are provided in Supplementary Table S1). N. tabacum elongation factor- $1 \alpha$ (EF1 $\alpha$ SGN-U446573) was used as an internal control after the evaluation of stability of four reference candidate genes (Supplementary Fig. S3). All primer sets are listed in Supplementary Table S2. RT-qPCR data analysis and primer efficiencies were obtained using LinRegPCR software (Ramakers et al. 2003). A reference gene was used to standardize the expression of a given target gene; then, a ratio between treatments was calculated using the algorithm developed by Pfaffl and associates (2002). Relative expression ratios and statistical analysis were performed using fgStatistics software interface (J. A. Di Rienzo, personal communications). The cut-off for statistically significant differences was set as *, $* *$, and $* * *$ indicate $P$ value $<0.05,0.01$, and 0.005 , respectively.

\section{ASC/DHA measurement.}

The method used to determine the amount of total (ASC) and oxidized (DHA) ascorbic acid uses high-performance liquid chromatography (HPLC) with amperometric electrochemical detection and it has been essentially described in a previous work (Diliberto et al. 1983). We made the following minor modifications to this protocol. Detection of ascorbic acid was achieved by injecting samples onto a silica-based, reversedphase $\mathrm{C}_{18}$ column (particle size $5 \mathrm{pm}, 150 \times 4.6 \mathrm{~mm}$, HL90-5s, Bio-Sil; Bio-Rad, Munich). The mobile phase consisted of a $\mathrm{KH}_{2} \mathrm{P} 04$ buffer $(100 \mathrm{mM})$ at $\mathrm{pH} 3.0$ (with phosphoric acid) and was delivered isocratically at a flow rate of $0.5 \mathrm{ml} / \mathrm{min}$. Ascorbic acid resulted in a peak at $3.5 \mathrm{~min}$. Total ASC (reduced plus oxidized) concentration was determined after reduction with dithiothreitol $(1 \mathrm{mM})$. The amount of oxidized DHA was then estimated as the difference in peak area between unreduced and reduced samples.

\section{SA and JA determination.}

Extraction and purification procedure. SA and JA were extracted from lyophilized leave tissues according to the protocol of Durgbanshi and associates (2005), with some modifications. For JA quantification, $100 \mathrm{ng}$ of JA (2 H6)-JA and 12-oxophytodienoic acid (2H5) OPDA were used as internal stand- 
ards. For SA quantification, the internal standard used was 100 ng of SA-(2H6).

Chromatography and mass spectrometry procedures (liquid chromatography electrospray with negative ionization tandem mass spectrometry). HPLC was performed using a Waters (Milford, MA, U.S.A.) Alliance 2690 system. Aliquots $(20 \mu \mathrm{l})$ were injected on a Nucleosil ODS reversed-phase column $\mathrm{C}_{18}$ (100 by $2.1 \mathrm{~mm}, 3 \mu \mathrm{m}$ ). Phytohormones were eluted using an initial gradient of $40 \%$ methanol and $60 \%$ water/ethanol and, 25 min later, with a gradient of $80 \%$ methanol and $20 \%$ water:ethanol. Identification and quantification were achieved introducing effluents with an electrospray with negative ionization tandem mass spectrometry into a triple-quadrupole mass spectrometer (Quattro Ultima; Micromass, Manchester, U.K.) from coupled HPLC. For identification, we used mass spectrometry operated with multiple reaction monitoring mode and MassLynx v.4.1 software (Micromass) and, for quantification, we used QuanLynx v.4.1 software (Micromass).

\section{TMV infection procedure.}

For inoculation, a single leaf of each plant was dusted with Carborundum and $20 \mu \mathrm{l}$ of semipurified TMV virus diluted in $20 \mathrm{mM} \mathrm{NaHPO}$ ( $\mathrm{pH}$ 7) was added; then, the surface of the leaf was gently abraded. The third leaf above the inoculated one was collected. For quantification of viral proteins, total proteins were extracted from the leaf tissues by using phosphate-buffered saline ( $\mathrm{pH}$ 7.2) and quantified with a Quick Start Bradford protein assay kit (Bio-Rad). For viral detection, ELISA experiments were performed as described previously (Bazzini et al. 2006).

TMV RNA in vitro transcription and tobacco inoculation.

For TMV RNA infections, cloned DNAs from TMV infectious viral RNAs were linearized with $K p n I$ and in vitro transcribed using a MEGAscript $\mathrm{T} 7$ in vitro transcription kit (Ambion, Austin, TX, U.S.A.). m7G (5')ppp (5')G Cap Analog (Ambion) was added to the reaction to synthesize $5^{\prime}$ capped RNA molecules. Transcripts were rubbed in one single leaf of 6-week-old tobacco plants as described above. Eight plants from each phenotype $\left(\mathrm{CP}^{\mathrm{T} 42 \mathrm{~W}}, \mathrm{MP}, \mathrm{MP} \times \mathrm{CP}^{\mathrm{T} 42 \mathrm{~W}}, \mathrm{mp} \times \mathrm{cp}^{\mathrm{T} 42 \mathrm{~W} *}\right.$, and SX controls) were used in this experiment and samples (two leaf discs from each plant) were collected at the indicated times. ELISA measurements where performed for each sample and medium, and standard error was calculated. The infection threshold was calculated using the average measurements of mock-inoculated plants plus three standard deviations. The assay was repeated three times with similar results. Statistical analyses were performed with Kruskal-Wallis and differences were calculated for samples from 10 and 25 dpi by comparing viral accumulation levels between transgenic plant lines and SX controls.

\section{$P$. syringae inoculation procedure.}

Bacterial strains and infection. $P$. syringae pv. tabaci strains (a gift from M. Alvarez) were cultured overnight in King's B medium containing antibiotic selection media rifampicin at 25 $\mathrm{mg} / \mathrm{liter}$ and tetracycline at $2 \mathrm{mg} / \mathrm{liter}$ at $28^{\circ} \mathrm{C}$ with $200 \mathrm{rpm}$ shaking; subsequently, they were centrifuged. Bacterial pellets were resuspended in $10 \mathrm{mM} \mathrm{MgCl}_{2}$ and adjusted to $10^{8}$ $\mathrm{CFU} / \mathrm{ml}$. Fully expanded leaves of 6-week-old tobacco plants were inoculated with bacteria or $10 \mathrm{mM} \mathrm{MgCl}$ (mock-inoculated plants) using a needless hypodermic syringe. The experiment was repeated twice with similar results.

Bacterial counts. At $48 \mathrm{~h}$ postinfiltration, leaf discs from infiltrated zones were collected in a $10 \mathrm{mM} \mathrm{MgCl} 2$ solution. To release bacteria, tissue was homogenized by grinding with a sterile pestle. Protein content was quantified with a Quick Start Brad- ford protein assay kit (Bio-Rad) and homogenized samples were adjusted to equivalent protein concentration. Then, 20- $\mu \mathrm{l}$ dilutions (concentration adjusted for 20 to 400 colonies/plate) were plated in King's B selective medium and incubated overnight at $28^{\circ} \mathrm{C}$. The bacterial plate count $=$ number of colonies/volume of plates $\times$ dilution factor. Statistical analyses were performed with Kruskal-Wallis and Dunns post test and differences were calculated between transgenic plant lines and SX controls.

\section{S. sclerotiorum inoculation procedure.}

A wild-type isolate of $S$. sclerotiorum (a gift from A. Escande and D. Barreto) was grown on potato dextrose agar plates as previously described by Godoy and associates (1990). After 4 days, 5-mm mycelia agar plugs were excised and inverted on the upper surface of 10 tobacco leaves per line. Infected leaves were excised, kept in petri plates containing a wet filter paper to ensure high humidity, and incubated at $26^{\circ} \mathrm{C}$ under a 24-h light photoperiod. Disease symptoms were observed every $24 \mathrm{~h}$ over a period of 6 days. The experiment was repeated twice and data of the representative experiment are shown. Statistical analysis were performed with one-way ANOVA and Dunnett post test by comparing leaf necrotic areas between transgenic plant lines and controls SX.

\section{GMP1 VIGS procedure.}

GMP1 cloning procedures and vector construction. To amplify a GMP1 cDNA fragment from $N$. tabacum, total RNA was isolated and subjected to RT-PCR using forward (5'-GT ACTCGGCTGAGGCCATTG-3') and reverse (5'-CCAGCAG GTAAATTCCAGCG -3') primers. The resulting 506-bp products were cloned into pCR8/GW/TOPO vector (Invitrogen) and verified by sequencing. GMP1 506-bp fragments were subcloned into a pTRV2-GW (Liu et al. 2002) vector by performing an LR recombination reaction. pTRV2-gmpl plasmids were electroporated into Agrobacterium sp. strain GV3101 and cells were grown on Luria-Bertani (LB) medium with gentamycin at $50 \mathrm{mg} / \mathrm{liter}$ and kanamycin at $50 \mathrm{mg} / \mathrm{liter}$.

Agroinfiltration and plant treatments. Agrobacterium GV3101 cultures containing the pTRV1, pTRV2-gfp (control), and pTRV2-gmpl cassettes were grown overnight at $28^{\circ} \mathrm{C}$ in $\mathrm{LB}$ selective medium. Cells were harvested by centrifugation and resuspended in infiltration media $\left(10 \mathrm{mM} \mathrm{MgCl}_{2}, 10 \mathrm{mM}\right.$ morpholine ethane sulfonic acid, and $200 \mathrm{mM}$ acetosyringone), adjusted to an optical density at $600 \mathrm{~nm}$ of 1, and kept at room temperature for 3 to $4 \mathrm{~h}$. Equivalent aliquots of GV3101pTRV1 and pTRV2 were mixed immediately before inoculation. $N$. benthamiana plants with four to five leaves were agroinfiltrated as previously described (Liu et al. 2002). Sample leaves were collected 20 days after infiltration, then immediately frozen in liquid nitrogen and stored at $-80^{\circ} \mathrm{C}$ until GMP1 silencing analysis by RT-qPCR. Primer sequences used were forward (5'-TTCCCAAAAATTGCAGCGG-3') and reverse (5'-CGCAACATCTG GTCCAATCAA-3') primers. In all, 15 plants from each genotype (NbTRV-gfp and NbTRV-gmpl) were used at the VIGS experiments.

\section{Statistical analysis.}

Statistical analysis were performed with one-way ANOVA test with Dunnett post-test GraphPad Prism 5 or Kruskal-Wallis using InfoStat software (InfoStat version 2008; Grupo InfoStat. FCA, Universidad Nacional de Córdoba, Argentina). The significance level for all post tests was $\alpha=0.05$.

\section{ACKNOWLEDGMENTS}

We thank J. Di Rienzo for assistance with microarray and RT-qPCR analysis, M. Alvarez from UNC (Córdoba, Argentina), who kindly pro- 
vided Pseudomonas syringae pv. tabaci isolates, A. Escande and D. Barreto from Instituto Nacional de Tecnología Agropecuaria (INTA, Buenos Aires, Argentina) for the generous gift of Sclerotinia sclerotiorum isolates; V. Mongelli, A. Bazzini, and F. Carrari for helpful discussions; and M. de Vas and J. Sabio y Garcia for assistance with English-language editing. This research was supported by PICT 2005 number 32598 from Agencia Nacional de Promoción Científica y Tecnológica (ANPCyT) and by project PE 243532 of the (INTA). G. Conti and M. C. Rodriguez hold a fellowship from CONICET and C. A. Manacorda a fellowship from INTA.

\section{LITERATURE CITED}

Abel, P. P., Nelson, R. S., De, B., Hoffmann, N., Rogers, S. G., Fraley, R. T., and Beachy, R. N. 1986. Delay of disease development in transgenic plants that express the tobacco mosaic virus coat protein gene. Science 232:738-743.

Able, A. J. 2003. Role of reactive oxygen species in the response of barley to necrotrophic pathogens. Protoplasma 221:137-143.

Alamillo, J. M., Saenz, P., and Garcia, J. A. 2006. Salicylic acid-mediated and RNA-silencing defense mechanisms cooperate in the restriction of systemic spread of plum pox virus in tobacco. Plant J. 48:217-227.

Almon, E., Horowitz, M., Wang, H. L., Lucas, W. J., Zamski, E., and Wolf, S. 1997. Phloem-specific expression of the Tobacco mosaic virus movement protein alters carbon metabolism and partitioning in transgenic potato plants. Plant Physiol. 115:1599-1607.

Alvarez, M.E. 2000. Salicylic acid in the machinery of hypersensitive cell death and disease resistance. Plant Mol. Biol. 44:429-442.

Apel, K., and Hirt, H. 2004. Reactive oxygen species: Metabolism, oxidative stress, and signal transduction. Annu. Rev. Plant Biol. 55:373-399.

Aranda, M., and Maule, A. 1998. Virus-induced host gene shutoff in animals and plants. Virology 243:261-267.

Aranda, M. A., Escaler, M., Wang, D., and Maule, A. J. 1996. Induction of HSP70 and polyubiquitin expression associated with plant virus replication. Proc. Natl. Acad. Sci. U.S.A. 93:15289-15293.

Asurmendi, S., Berg, R. H., Koo, J. C., and Beachy, R. N. 2004. Coat protein regulates formation of replication complexes during Tobacco mosaic virus infection. Proc. Natl. Acad. Sci. U.S.A. 101:1415-1420.

Asurmendi, S., Berg, R. H., Smith, T. J., Bendahmane, M., and Beachy, R. N. 2007. Aggregation of TMV CP plays a role in CP functions and in coat-protein-mediated resistance. Virology 366:98-106.

Atkins, D., Hull, R., Wells, B., Roberts, K., Moore, P., and Beachy, R. N. 1991. The tobacco mosaic virus $30 \mathrm{~K}$ movement protein in transgenic tobacco plants is localized to plasmodesmata. J. Gen. Virol. 72:209211

Baebler, S., Stare, K., Kovac, M., Blejec, A., Prezelj, N., Stare, T., Kogovsek, P., Pompe-Novak, M., Rosahl, S., Ravnikar, M., and Gruden, K. 2011. Dynamics of responses in compatible potato-Potato virus $Y$ interaction are modulated by salicylic acid. PLoS One 6:e29009. Published online.

Bajda, A., Konopka-Postupolska, D., Krzymowska, M., Hennig, J., Skorupinska-Tudek, K., Surmacz, L., Wojcik, J., Matysiak, Z., Chojnacki, T., Skorzynska-Polit, E., Drazkiewicz, M., Patrzylas, P., Tomaszewska, M., Kania, M., Swist, M., Danikiewicz, W., Piotrowska, W., and Swiezewska, E. 2009. Role of polyisoprenoids in tobacco resistance against biotic stresses. Physiol. Plant. 135:351-364.

Balachandran, S., Hull, R. J., Martins, R. A., Vaadia, Y., and Lucas, W. J. 1997. Influence of environmental stress on biomass partitioning in transgenic tobacco plants expressing the movement protein of tobacco mosaic virus. Plant Physiol. 114:475-481.

Barth, C., Moeder, W., Klessig, D. F., and Conklin, P .L. 2004. The timing of senescence and response to pathogens is altered in the ascorbatedeficient Arabidopsis mutant vitamin c-1. Plant Physiol. 134:17841792

Bazzini, A. A., Asurmendi, S., Hopp, H. E., and Beachy, R. N. 2006. Tobacco mosaic virus (TMV) and Potato virus $X$ (PVX) coat proteins confer heterologous interference to PVX and TMV infection, respectively. J. Gen. Virol. 87:1005-1012.

Bazzini, A. A., Hopp, H. E., Beachy, R. N., and Asurmendi, S. 2007. Infection and coaccumulation of Tobacco mosaic virus proteins alter microRNA levels, correlating with symptom and plant development. Proc. Natl. Acad. Sci. U.S.A. 104:12157-12162.

Bazzini, A. A., Manacorda, C. A., Tohge, T., Conti, G., Rodriguez, M. C., Nunes-Nesi, A., Villanueva, S., Fernie, A. R., Carrari, F., and Asurmendi, S. 2011. Metabolic and miRNA profiling of TMV infected plants reveals biphasic temporal changes. PLoS One 6:e28466. Published online.

Beachy, R. N. 1999. Coat-protein-mediated resistance to tobacco mosaic virus: Discovery mechanisms and exploitation. Philos. Trans. R. Soc. of Lond. 354:659-664.

Beffa, R. S., Hofer, R. M., Thomas, M., and Meins, F., Jr. 1996. Decreased susceptibility to viral disease of [beta]-1,3-glucanase-deficient plants generated by antisense transformation. Plant Cell 8:1001-1011.

Bendahmane, M., Fitchen, J. H., Zhang, G., and Beachy, R. N. 1997. Studies of coat protein-mediated resistance to tobacco mosaic tobamovirus: Correlation between assembly of mutant coat proteins and resistance. J. Virol. 71:7942-7950.

Bendahmane, M., Szecsi, J., Chen, I., Berg, R. H., and Beachy, R. N. 2002. Characterization of mutant tobacco mosaic virus coat protein that interferes with virus cell-to-cell movement. Proc. Natl. Acad. Sci. U.S.A. 99:3645-3650.

Benjamini, Y., and Hochberg, Y. 1995. Controlling the false discovery rate: A practical and powerful approach to multiple testing. J. R. Stat. Soc. Ser. B :289-300.

Callaway, A., Giesman-Cookmeyer, D., Gillock, E. T., Sit, T. L., and Lommel, S. A. 2001. The multifunctional capsid proteins of plant RNA viruses. Annu. Rev. Phytopathol. 39:419-460.

Carr, J. P., Beachy, R. N., and Klessig, D. F. 1989. Are the PR1 proteins of tobacco involved in genetically engineered resistance to TMV? Virology 169:470-473

Cecchini, E., Gong, Z., Geri, C., Covey, S. N., and Milner, J. J. 1997. Transgenic Arabidopsis lines expressing gene VI from cauliflower mosaic virus variants exhibit a range of symptom-like phenotypes and accumulate inclusion bodies. Mol. Plant-Microbe Interact. 10:10941101

Chivasa, S., Murphy, A. M., Naylor, M., and Carr, J. P. 1997. Salicylic acid interferes with tobacco mosaic virus replication via a novel salicylhydroxamic acid-sensitive mechanism. Plant Cell 9:547-557.

Colville, L., and Smirnoff, N. 2008. Antioxidant status, peroxidase activity, and PR protein transcript levels in ascorbate-deficient Arabidopsis thaliana vtc mutants. J. Exp. Bot. 59:3857-3868.

Conklin, P. L., Saracco, S. A., Norris, S. R., and Last, R. L. 2000. Identification of ascorbic acid-deficient Arabidopsis thaliana mutants. Genetics 154:847-856

Curaba, J., and Chen, X. 2008. Biochemical activities of Arabidopsis RNA-dependent RNA polymerase 6. J. Biol. Chem. 283:3059-3066.

Cutt, J. R., Harpster, M. H., Dixon, D. C., Carr, J. P., Dunsmuir, P., and Klessig, D. F. 1989. Disease response to tobacco mosaic virus in transgenic tobacco plants that constitutively express the pathogenesis-related PR1b gene. Virology 173:89-97.

Dat, J., Vandenabeele, S., Vranova, E., Van Montagu, M., Inze, D., and Van Breusegem, F. 2000. Dual action of the active oxygen species during plant stress responses. Cell. Mol. Life Sci. 57:779-795.

Dat, J. F., Pellinen, R., Beeckman, T., Van De Cotte, B., Langebartels, C., Kangasjarvi, J., Inze, D., and Van Breusegem, F. 2003. Changes in hydrogen peroxide homeostasis trigger an active cell death process in tobacco. Plant J. 33:621-632.

Deom, C. M., Oliver, M. J., and Beachy, R. N. 1987. The 30-kilodalton gene product of tobacco mosaic virus potentiates virus movement. Science 237:389-394.

Deom, C. M., Schubert, K. R., Wolf, S., Holt, C. A., Lucas, W. J., and Beachy, R. N. 1990. Molecular characterization and biological function of the movement protein of tobacco mosaic virus in transgenic plants. Proc. Natl. Acad. Sci. U.S.A. 87:3284-3288

Diaz-Vivancos, P., Clemente-Moreno, M. J., Rubio, M., Olmos, E., Garcia, J. A., Martinez-Gomez, P., and Hernandez, J. A. 2008. Alteration in the chloroplastic metabolism leads to ROS accumulation in pea plants in response to plum pox virus. J. Exp. Bot. 59:2147-2160.

Diliberto, E. J., Heckman, G. D., and Daniels, A. J. 1983. Characterization of ascorbic acid transport by adrenomedulary chromaffin cells. J. Biol. Chem. 258:12886-12894.

Durgbanshi, A., Arbona, V., Pozo, O., Miersch, O., Sancho, J. V., and Gomez-Cadenas, A. 2005. Simultaneous determination of multiple phytohormones in plant extracts by liquid chromatography-electrospray tandem mass spectrometry. J. Agric. Food Chem. 53:8437-8442.

Durrant, W. E., and Dong, X. 2004. Systemic acquired resistance. Annu. Rev. Phytopathol. 42:185-209.

Edreva, A. 2005. Pathogenesis-related proteins: Research progress in the last 15 years. Gen. Appl. Plant Physiol. 31:105-124.

Epel, B. L. 2009. Plant viruses spread by diffusion on ER-associated movement-protein-rafts through plasmodesmata gated by viral induced host beta-1,3-glucanases. Semin. Cell Dev. Biol. 20:1074-1081.

Faize, M., Burgos, L., Faize, L., Petri, C., Barba-Espin, G., Díaz-Vivancos, P., Clemente-Moreno, M. J., Alburquerque, N., and Hernandez, J. A. 2011. Modulation of tobacco bacterial disease resistance using cytosolic ascorbate peroxidase and $\mathrm{Cu}, \mathrm{Zn}$-superoxide dismutase. Plant Pathol. Doi: 10.1111/j.1365-3059.2011.02570.x. Published online.

Fodor, J., Gullner, G., Adam, A. L., Barna, B., Komives, T., and Kiraly, Z. 1997. Local and systemic responses of antioxidants to tobacco mosaic virus infection and to salicylic acid in tobacco (role in systemic acquired resistance). Plant Physiol. 114:1443-1451. 
Foyer, C. H., Kiddle, G., and Verrier, P. 2007. Transcriptional profiling approaches to understanding how plants regulate growth and defence: A case study illustrated by analysis of the role of vitamin C. EXS 97:5586.

Garcia-Ruiz, H., Takeda, A., Chapman, E. J., Sullivan, C. M., Fahlgren, N., Brempelis, K. J., and Carrington, J. C. 2010. Arabidopsis RNAdependent RNA polymerases and dicer-like proteins in antiviral defense and small interfering RNA biogenesis during Turnip mosaic virus infection. Plant Cell 22:481-496.

Godoy, G., Steadman, J. R., Dickman, M. B., and Dam, R. 1990. Use of mutants to demonstrate the role of oxalic acid in pathogenicity of Sclerotinia sclerotiorum on Phaseolus vulgaris. Physiol. Mol. Plant Pathol. 37:179-191.

Govrin, E. M., and Levine, A. 2000. The hypersensitive response facilitates plant infection by the necrotrophic pathogen Botrytis cinerea. Curr. Biol. 10:751-757.

Grant, M., and Lamb, C. 2006. Systemic immunity. Curr. Opin. Plant Biol. 9:414-420.

Guenoune-Gelbart, D., Elbaum, M., Sagi, G., Levy, A., and Epel, B. L. 2008. Tobacco mosaic virus (TMV) replicase and movement protein function synergistically in facilitating TMV spread by lateral diffusion in the plasmodesmal desmotubule of Nicotiana benthamiana. Mol. Plant-Microbe Interact. 21:335-345.

Harries, P. A., Palanichelvam, K., Bhat, S., and Nelson, R. S. 2008. Tobacco mosaic virus $126-\mathrm{kDa}$ protein increases the susceptibility of Nicotiana tabacum to other viruses and its dosage affects virus-induced gene silencing. Mol. Plant-Microbe Interact. 21:1539-1548.

Havelda, Z., and Maule, A. J. 2000. Complex spatial responses to Cucumber mosaic virus infection in susceptible Cucurbita pepo cotyledons. Plant Cell 12:1975-1986.

Havelda, Z., Varallyay, E., Valoczi, A., and Burgyan, J. 2008. Plant virus infection-induced persistent host gene downregulation in systemically infected leaves. Plant J. 55:278-288.

Hilf, M. E., and Dawson, W. O. 1993. The tobamovirus capsid protein functions as a host-specific determinant of long-distance movement. Virology 193:106-114.

Huang, Z., Yeakley, J. M., Garcia, E. W., Holdridge, J. D., Fan, J. B., and Whitham, S. A. 2005. Salicylic acid-dependent expression of host genes in compatible Arabidopsis-virus interactions. Plant Physiol. 137:11471159.

Irizarry, R. A., Bolstad, B. M., Collin, F., Cope, L. M., Hobbs, B., and Speed, T. P. 2003. Summaries of Affymetrix GeneChip probe level data. Nucleic Acids Res. 31:e15.

Jockusch, H., Wiegand, C., Mersch, B., and Rajes, D. 2001. Mutants of Tobacco mosaic virus with temperature-sensitive coat proteins induce heat shock response in tobacco leaves. Mol. Plant-Microbe Interact. 14:914-917.

Jones, J. D., and Dangl, J. L. 2006. The plant immune system. Nature 444:323-329.

Jovel, J., Walker, M., and Sanfacon, H. 2011. Salicylic acid-dependent restriction of Tomato ringspot virus spread in tobacco is accompanied by a hypersensitive response, local RNA silencing, and moderate systemic resistance. Mol. Plant-Microbe Interact. 24:706-718

Li, A. L., Wang, M. L., Zhou, R. H., Kong, X. Y., Huo, N. X., Wang, W. S., and Jia, J. Z. 2005. Comparative analysis of early $\mathrm{H}_{2} \mathrm{O}_{2}$ accumulation in compatible and incompatible wheat-powdery mildew interactions. Plant Pathol. 54:308-316.

Liao, Y. W., Shi, K., Fu, L. J., Zhang, S., Li, X., Dong, D. K., Jiang, Y. P., Zhou, Y. H., Xia, X. J., Liang, W. S., and Yu, J. Q. 2012. The reduction of reactive oxygen species formation by mitochondrial alternative respiration in tomato basal defense against TMV infection. Planta 235:225238

Linthorst, H. J., Meuwissen, R. L., Kauffmann, S., and Bol, J. F. 1989. Constitutive expression of pathogenesis-related proteins PR-1, GRP, and PR-S in tobacco has no effect on virus infection. Plant Cell 1:285291

Liu, Y., Schiff, M., and Dinesh-Kumar, S. P. 2002. Virus-induced gene silencing in tomato. Plant J. 31:777-786.

Loake, G., and Grant, M. 2007. Salicylic acid in plant defence-the players and protagonists. Curr. Opin. Plant Biol. 10:466-472.

Lorrain, S., Vailleau, F., Balague, C., and Roby, D. 2003. Lesion mimic mutants: Keys for deciphering cell death and defense pathways in plants? Trends Plant Sci. 8:263-271.

Malamy, J., Carr, J. P., Klessig, D. F., and Raskin, I. 1990. Salicylic acid: A likely endogenous signal in the resistance response of tobacco to viral infection. Science 250:1002-1004.

Maule, A., Leh, V., and Lederer, C. 2002. The dialogue between viruses and hosts in compatible interactions. Curr. Opin. Plant Biol. 5:279-284.

Mayer, M. P. 2005. Recruitment of Hsp70 chaperones: A crucial part of viral survival strategies. Rev. Physiol. Biochem. Pharmacol. 153:1-46.
Mittler, R. 2002. Oxidative stress, antioxidants and stress tolerance. Trends Plant Sci. 7:405-410.

Mittler, R., Feng, X., and Cohen, M. 1998. Post-transcriptional suppression of cytosolic ascorbate peroxidase expression during pathogeninduced programmed cell death in tobacco. Plant Cell 10:461-473.

Mittler, R., Herr, E. H., Orvar, B. L., van Camp, W., Willekens, H., Inze, D., and Ellis, B. E. 1999. Transgenic tobacco plants with reduced capability to detoxify reactive oxygen intermediates are hyperresponsive to pathogen infection. Proc. Natl. Acad. Sci. U.S.A. 96:14165-14170.

Mittler, R., Vanderauwera, S., Suzuki, N., Miller, G., Tognetti, V. B., Vandepoele, K., Gollery, M., Shulaev, V., and Van Breusegem, F. 2011. ROS signaling: The new wave? Trends Plant Sci. 16:300-309.

Mukherjee, M., Larrimore, K. E., Ahmed, N. J., Bedick, T. S., Barghouthi, N. T., Traw, M. B., and Barth, C. 2010. Ascorbic acid deficiency in Arabidopsis induces constitutive priming that is dependent on hydrogen peroxide, salicylic acid, and the NPR1 gene. Mol. Plant-Microbe Interact. 23:340-351.

Murphy, A. M., and Carr, J. P. 2002. Salicylic acid has cell-specific effects on tobacco mosaic virus replication and cell-to-cell movement. Plant Physiol. 128:552-563.

Naylor, M., Murphy, A. M., Berry, J. O., and Carr, J. P. 1998. Salicylic acid can induce resistance to plant virus movement. Mol. Plant-Microbe Interact. 11:860-868.

Nelson, R. S., Abel, P. P., and Beachy, R. N. 1987. Lesions and virus accumulation in inoculated transgenic tobacco plants expressing the coat protein gene of tobacco mosaic virus. Virology 158:126-132.

$\mathrm{Nie}, \mathrm{X} .2006$. Salicylic acid suppresses Potato virus $Y$ isolate N:O-induced symptoms in tobacco plants. Phytopathology 96:255-263.

Niehl, A., and Heinlein, M. 2011. Cellular pathways for viral transport through plasmodesmata. Protoplasma 248:75-99.

Pallas, V., and Garcia, J. A. 2011. How do plant viruses induce disease? Interactions and interference with host components. J. Gen. Virol 92:2691-2705.

Palukaitis, P., Carr, J. P., and Schoelz, J. E. 2008. Plant-virus interactions. Methods Mol. Biol. 451:3-19.

Pastori, G. M., Kiddle, G., Antoniw, J., Bernard, S., Veljovic-Jovanovic, S., Verrier, P. J., Noctor, G., and Foyer, C. H. 2003. Leaf vitamin C contents modulate plant defense transcripts and regulate genes that control development through hormone signaling. Plant Cell 15:939-951.

Pavet, V., Olmos, E., Kiddle, G., Mowla, S., Kumar, S., Antoniw, J., Alvarez, M. E., and Foyer, C. H. 2005. Ascorbic acid deficiency activates cell death and disease resistance responses in Arabidopsis. Plant Physiol. 139:1291-1303.

Pfaffl, M. W., Horgan, G. W., and Dempfle, L. 2002. Relative expression software tool (REST) for group-wise comparison and statistical analysis of relative expression results in real-time PCR. Nucleic Acids Res. 30:e36.

Pnueli, L., Liang, H., Rozenberg, M., and Mittler, R. 2003. Growth suppression, altered stomatal responses, and augmented induction of heat shock proteins in cytosolic ascorbate peroxidase (Apx1)-deficient Arabidopsis plants. Plant J. 34:187-203.

Ramakers, C., Ruijter, J. M., Deprez, R. H., and Moorman, A. F. 2003. Assumption-free analysis of quantitative real-time polymerase chain reaction (PCR) data. Neurosci. Lett. 339:62-66.

Rensink, W. A., Lee, Y., Liu, J., Iobst, S., Ouyang, S., and Buell, C. R. 2005. Comparative analyses of six solanaceous transcriptomes reveal a high degree of sequence conservation and species-specific transcripts. BMC Genomics 6:124

Riedle-Bauer, M. 2000. Role of reactive oxygen species and antioxidant enzymes in systemic virus infections of plants. J. Phytopathol. 148:297302.

Shimizu, T., Satoh, K., Kikuchi, S., and Omura, T. 2007. The repression of cell wall- and plastid-related genes and the induction of defense-related genes in rice plants infected with Rice dwarf virus. Mol. Plant-Microbe Interact. 20:247-254

Thimm, O., Blasing, O., Gibon, Y., Nagel, A., Meyer, S., Kruger, P., Selbig, J., Muller, L. A., Rhee, S. Y., and Stitt, M. 2004. MAPMAN: A user-driven tool to display genomics data sets onto diagrams of metabolic pathways and other biological processes. Plant J. 37:914-939.

Thordal-Christensen, H., Zhang, Z., Wei, Y., and Collinge, D. B. 1997. Subcellular localization of $\mathrm{H}_{2} \mathrm{O}_{2}$ in plants, $\mathrm{H}_{2} \mathrm{O}_{2}$ accumulation in papillae and hypersensitive response during the barley-powdery mildew interaction. Plant J. 11:1187-1194.

Urbanek Krajnc, A., Kristl, J., and Ivancic, A. 2011. Application of salicylic acid induces antioxidant defense responses in the phloem of Picea abies and inhibits colonization by Ips typographus. For. Ecol. Manage. 261:416-426.

van Loon, L. C., Rep, M., and Pieterse, C. M. 2006. Significance of inducible defense-related proteins in infected plants. Annu. Rev. Phytopathol. 44:135-162. 
Vlot, A. C., Dempsey, D. A., and Klessig, D. F. 2009. Salicylic acid, a multifaceted hormone to combat disease. Annu. Rev. Phytopathol. 47:177-206.

Vogler, H., Kwon, M. O., Dang, V., Sambade, A., Fasler, M., Ashby, J., and Heinlein, M. 2008. Tobacco mosaic virus movement protein enhances the spread of RNA silencing. PLoS Pathog. 4:e1000038. Published online.

Whitham, S. A., Quan, S., Chang, H. S., Cooper, B., Estes, B., Zhu, T., Wang, X., and Hou, Y. M. 2003. Diverse RNA viruses elicit the expression of common sets of genes in susceptible Arabidopsis thaliana plants. Plant J. 33:271-283.

Whitham, S. A., Yang, C., and Goodin, M. M. 2006. Global impact: Elucidating plant responses to viral infection. Mol. Plant-Microbe Interact. 19:1207-1215.

Wise, R. P., Moscou, M. J., Bogdanove, A. J., and Whitham, S. A. 2007. Transcript profiling in host-pathogen interactions. Annu. Rev. Phytopathol. 45:329-369.

Wohlgemuth, H. M. K., Kschieschan, S., Bender, J., Weigel, H.-J., Overmeyer, K, Kangasjarvi, J., Sandermann, H., and Langebartels, G. 2002. Activation of an oxidative burst is a general feature of sensitive plants exposed to the air pollutant ozone. Plant Cell Environ. 25:717726.

Wolf, S., Deom, C. M., Beachy, R. N., and Lucas, W. J. 1989. Movement protein of tobacco mosaic virus modifies plasmodesmatal size exclusion limit. Science 246:377-379.
Xie, Z., Fan, B., Chen, C., and Chen, Z. 2001. An important role of an inducible RNA-dependent RNA polymerase in plant antiviral defense. Proc. Natl. Acad. Sci. U.S.A. 98:6516-6521.

Yang, Y., Shah, J., and Klessig, D. F. 1997. Signal perception and transduction in plant defense responses. Genes Dev. 11:1621-1639.

Yi, S. Y., Yu, S. H., and Choi, D. 1999. Molecular cloning of a catalase cDNA from Nicotiana glutinosa L. and its repression by tobacco mosaic virus infection. Mol. Cells 9:320-325.

Yi, S. Y., Yu, S. H., and Choi, D. 2003. Involvement of hydrogen peroxide in repression of catalase in TMV-infected resistant tobacco. Mol. Cells 15:364-369.

Zijlstra, C., Scharer-Hernandez, N., Gal, S., and Hohn, T. 1996. Arabidopsis thaliana expressing the cauliflower mosaic virus ORF VI transgene has a late flowering phenotype. Virus Genes 13:5-17.

\section{AUTHOR-RECOMMENDED INTERNET RESOURCES}

The National Center for Biotechnology Information website: www.ncbi.nlm.nih.gov

Sol Genomics Network website: solgenomics.net

InfoStat software: www.infostat.com.ar

fgStatistics software: sites.google.com/site/fgStatistics

GraphPad software: www.graphpad.com 